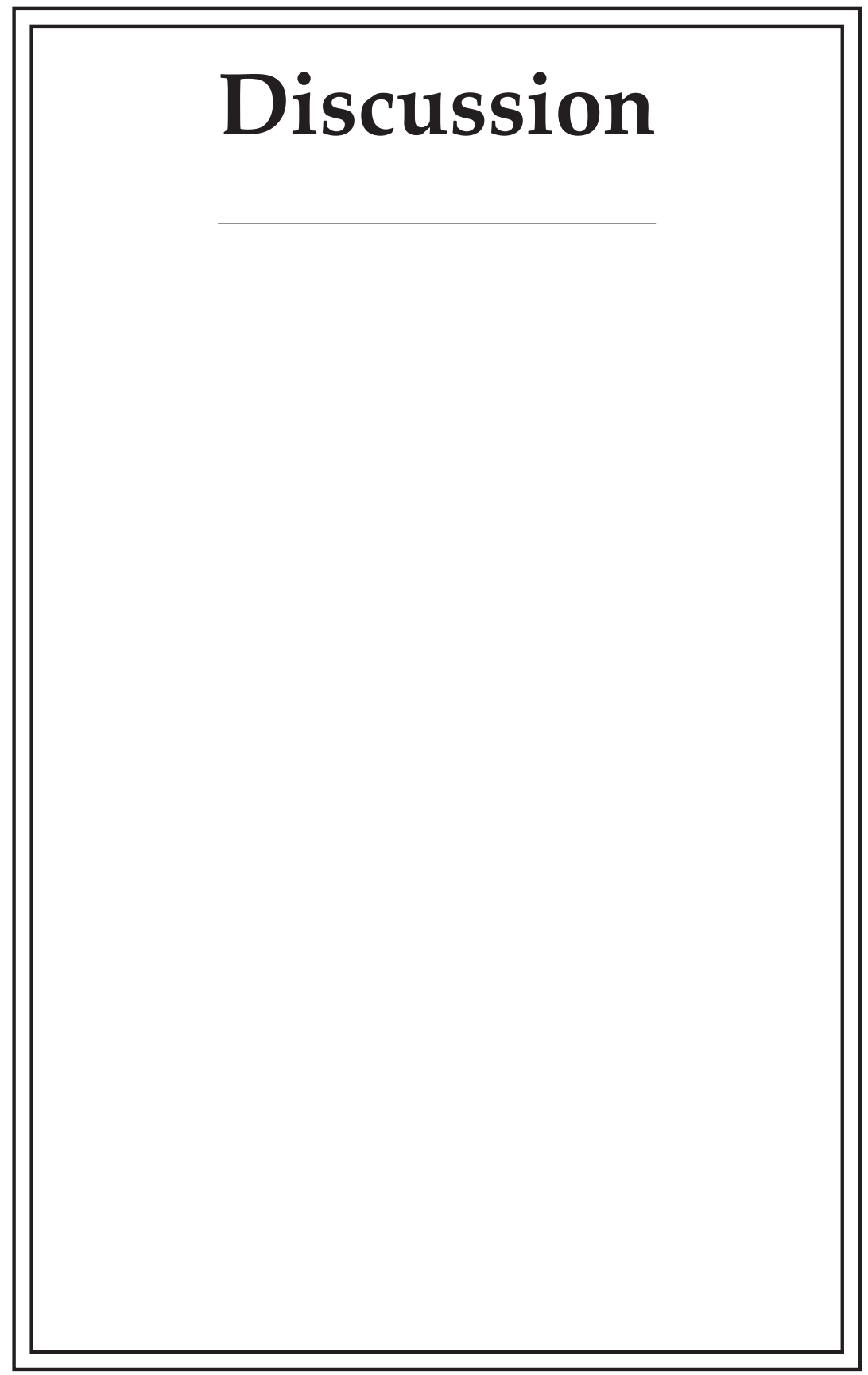




\section{ПО ПОВОДУ РЕЦЕНЗИИ П. В. АУКИНА «ДЕКОНСТРУКЦИЯ ДЕКОНСТРУКЦИИ»}

...et dum alienos errores emendore nituntur, ostendunt suos

Hieronimus

В предыдущем номере Scrinium появилась рецензия П. В. Аукина на мою книгу «Дюдье и князь в конструкциях летописцев XI-XIII вв.» ${ }^{1}$ Рецензия написана с позиции исследователя, подчеркивающего свою «традиционность», и содержит множество критических замечаний как частного, так и общего плана. Прежде всего, хотелось бы отметить, что я чрезвычайно признательна П. В. Лукину за указание на ошибки, и приношу читателям свои извинения за допущенные неточности. К сожалению, в монографии действительно оказался ряд недочетов, связанных как с некоторыми огрехами при работе с огромным массивом источников и цитируемых текстов, так и, увы, с естественной ограниченностью знаний автора. К примеру, в Ипатьевском списке под 1151 г. читается «рекуче», а не «рекоша» (последнее в Хиебниковском), имеется погрешность в написании фамилии Zernack, в одной из записей Киевского свода было пропущено титло, что привело к смещению смысла известия. Указания на подобные недочеты работы являются очень полезными и с искренней благодарностью принимаются. Вместе с тем, следует отметить, что все они касаются «технической» стороны дела и никак не вдияют на результаты исследования.

Примечательно, что П. В. Аукин на 30 страницах своей объемистой рецензии не изложил содержания рецензируемой им книги и не охарактеризовал ее структуру. Из этой рецензии никакого общего впечатления о работе составить невозможно, и в чем состоит «нарративизм» автора и в чем «традиционность» рецензента, совершенно неясно. В целом, читатель из этого текста узнает только то, что автор рецензируемой монографии отличается высокомерным отношением ко всем предшествующим научным достижениям в причудливом соединении с просто редкой некомпетентностью. К сожалению, ре-

(1) П. В. Аукин, Деконструкция деконструкции. О книге Т. А. Вилкул по истории древнерусского веча, Scr 4 (2008) 403-434. 
цензент не внес ясность в некоторые базовые вопросы и не уточнил, в чем суть монографии. Попытаемся восполнить этот пробел.

Прежде всего, несколько слов о терминологии. П. В. Аукин назвал свою рецензию «Деконструкция деконструкции» и неоднократно обыграл это слово, а также слово «нарратив» и его производные (не всегда, впрочем, верно и к месту употребляя соответствующие понятия). Однако, «деконструкция» в моей книге не используется ни разу. В монографии действительно исследуются нарративные модели древнерусских летописей, применительно к тем случаям, когда в источниках описываются взаимоотношения народа и правителя. Но отождествлять исследование нарратива и деконструкцию неверно, как неверно и то, что подобные исследования непременно должны приводить к принятию непознаваемости реадьности и погружению исключительно в реальность текста. ${ }^{2}$ Сам термин «деконструкция» не является необходимым и обязатедьным в подобных работах. Он, конечно, широко употреблялся одно время, в особенности французскими интеллектуалами. Соответственно, впоследствии стал модным, а затем даже несколько заезженным, появляясь и в высказываниях далеко не интеллектуальных персонажей. Понятие «нарратив» также не относится к ругательным. Оно обозначает 'повествование', 'рассказ' (или, в более специальном значении, 'определенный вид повествования'). Тем не менее, «нарратив» предпочтительнее в научной литературе, поскольку «повествование» и «рассказ» - слова многозначные. Точно так же, не являются ругательными понятия «конструирование» и «нарративное конструирование». В любом случае, в книге речь идет не о деконструкции, а об определении формантов летописных известий и нарративных моделей в целом.

Итак, о чем рецензируемая П. В. Аукиным книга? (коль уж рецензент никак не обозначил содержание, по-видимому, необходимо исправить это упущение). Книга посвящена взаимоотношениям народа и правителя в Древней Руси, в частности, рассматривается такой феномен, как древнерусское вече. Автор сосредоточился на определении принципов описания взаимоотношений «людей» и князя и рассматривает их через призму нарративных конструкций и представлений древнерусских летописцев. Делаются также попыт-

(2) См. замечания П. В. Аукина на с. 404, завершающиеся словами: «не будем придираться к теоретической путанице». Познание действительности, в том числе в раздичных науках, является гораздо бодее сложным феноменом, чем предполагалось. См., напр.: Т. Кун, Структура научных революций (Москва, 1977) (этого автора не причисляют к постструктурадистам, поскольку он принадлежит к предыдущему поколению). 
ки реконструкции реалий: определения состава и компетенции веча. Монография состоит из вступления и 4-х глав, прилагается указатель имен и географических названий. В первой главе анализируются особенности «социальной» терминологии древнерусских яетописей XIXIII вв. Исследуется слово «вече» и сфера его значений, соотношение прямых и непрямых упоминаний о вече, ${ }^{3}$ специфика использования таких летописных обозначений, как «дюдие», «народъ», «весь градъ», «дружина», «съборъ», «бояре», «от мала и до велика», «съборъ». Словоупотребление ранних древнерусских летописей сравнивается со словоупотреблением в отдельных книгах Священного Писания, хронографических текстах, житийной дитературе. Делаются подсчеты частоты употребления, уточняется значение слов и формульный ряд. Вторая глава - «Нарративное конструирование в параллельных сюжетах летописных сводов». Исследуются более двух десятков летописных сообщений, для каждого из которых мы имеем по две или более версий, где изложение событий разнится, иногда доходя до зеркальной противоположности. Показывается, что раздичия в изложении, наблюдаемые в параллельных летописных текстах, не бессистемны, в сюжетах прослеживаются устойчивые комплексы формантов (основных элементов повествования). Описываются три нарративные модели; отмечено, что в двух из них выступления «дюдей» фиксируются летописцами только в том случае, если необходимо оправдание и одобрение поступков князя; напр., на людей воздагается ответственность за жестокость, проявленную по отношению к подитическим оппонентам. В третьей главе, «Состав и функции веча», сделана попытка очертить социальный состав и компетенцию веча, выясняются возможности решения проблемы на имеющемся материале и ограничения, накладываемые на исследовательские решения нарративными источниками. В древнерусских текстах прослеживается принцип репрезентативности, позволяющий в большинстве случаев замещение больших групп малыми и наоборот. Вследствие чего, князь или несколько самых знатных людей могли представдять «всю землю»; в тех же случаях, когда перед летописцем стояла задача скрыть недостойные поступки князя, «дюдие» «замещади» верхушку. К сожалению, социальный состав, количество участников, частота собраний не поддаются точному определению. Тем не менее, имеется и положительный результат - можно предполагать, что вече и дружина не были жестко отграниченными одна от другой общнос-

(3) Т. е. таких известий, где имеется слово «въче» и таких, где оно отсутствует, и вечевое выступление определяется по тем иди иным косвенным признакам. 
тями. По-видимому, в ситуации политической стабильности в их состав входили одни и те же люди, составлявшие верхушку общества. Раскол местного социума происходил тогда, когда шла борьба между двумя лидерами (князьями). В последней главе систематизируются данные о представлениях яетописцев о взаимоотношениях правителя и народа. В том числе, сделана попытка объяснить тот факт, что в описаниях деятельности «людей» в центре внимания книжников неизменно стоит князь; рассматриваются представления о законности и незаконности вечевых собраний, проистекающей, как выясняется, из оценки «верности» и «неверности» горожан, единства и разделения участников собраний, а также тревожности всех сообщений подобной тематики.

Собственно говоря, многие положения и исследуемые вопросы являются вполне традиционными. В частности, первая глава, посвященная социальной терминологии (ср. напр., работы А. С. Аьвова, А. А. Горского, С. В. Завадской и многих других). Разве что материал взят в соответствии с темой монографии - рассматриваются обозначения, которые использовались в описаниях взаимоотношений народа и правителя, и акцентируется неустойчивость терминологии. Далее, о том, что повествование летописей не столько отражает действительность, сколько конструировано - ныне мнение почти общепринятое и отнюдь не «экстремистское». Много внимания учеными уделяется поиску книжных образцов летописных текстов, в том числе - библейских. ${ }^{4}$ Новизна исследования состоит в том, что построенными согласно определенным нарративным моделям признаются сугубо светские рассказы летописей. Полагаю, что обнаруженные серии параллельных известий, когда в одной из летописей то или иное деяние приписывается князю, а в другой - горожанам, необходимо объяснять, и методика сравнения летописных текстов и выявления нарративных моделей предоставдяет необходимые для этого инструменты. Новые подходы использовались также при рассмотрении представлений летописцев о взаимоотношениях народа и правителя (для разработки этой проблемы до обнаружения параллельных версий было недостаточно материала).

(4) Следует отметить, это весьма традиционное направление, в том числе, в российской науке, поиск ведется не только в летописях, но и в западноевропейских хрониках. См., напр.: Д. Егоров, Новый источник по истории прибалтийского славянства, в: Сборник статей, посвященных В. О. Ключевскому его учениками, друзьями, почитателями ко дню 30-летия его профессорской деятельности в Московском университете (5 декабря 1880 - 5 декабря 1909) (Москва, 1909) 332-346. 
Анализу основных положений и аргументов рецензент предпочитает сугубый анализ деталей, и изучает их настолько скрупулезно, что неоднократно разбирает подробно окончание какого-нибудь примечания, каковых в книге более 1000. При всем уважении к проделанной им огромной работе нельзя не указать не вполне верную ее направленность. Среди орудий, привычных для «рецензионной кухни» П. В. Аукина, попадаются своеобычные. К примеру, часто дискуссионные темы и вопросы он излагает так, будто речь идет о твердо установленных вещах. В таких случаях у читателя неизбежно создается впечатление, что автор по своему недомыслию или невежеству нарушил общепринятые конвенции (а не предпочел то или иное решение в научной дискуссии). Порой рецензент, видимо, сам того не замечая, подменяет написанное в книге совершенно чуждыми утверждениями, а в иных случаях неверно понимает написанное. Встречается и такое, что, предлагая «корректное» прочтение взамен, по его мнению, «некорректного», рецензент обнаруживает слабое знакомство с текстами, которые необходимо было проанадизировать.

Форма рецензии П. В. Аукина предполагает соответствующую структуру ответа - приходится следовать его «деконструкциям». Хотелось бы остановиться на высказываниях, не соответствующих действительному положению вещей. Разумеется, все их охватить невозможно, ибо рецензент своеобразные приемы использует достаточно часто, но я попытаюсь к каждому параграфу предложить несколько комментариев. При необходимости уточнений, приводятся отрывки из моей книги. Так как далее речь часто будет идти о летописях, привожу принятые сокращения: Ипат. (у рецензента Ип.) - Ипатьевская летопись, Лавр. - Лаврентьевская, НП летопись, МАС - Московский летописный свод конца XV в.

\section{По поводу «деконструкции историографии».}

По словам рецензента, в монографии из-за «высокомерного отношения автора к предшествующей историографии» дан только краткий обзор литературы. Правда, в книге на с.8 в книге прямо указано, что детальная разработка историографических проблем при том интересе, который историки традиционно проявляли к вопросу о взаимоотношениях правителя и народа, потребовала бы отдельной монографии. ${ }^{5}$ Но П. В. Аукин, очевидно, полагает объяснение автора несущес-

(5) См.: «Если заняться исключительно тем, что уже написано историками о вече, этим материалом можно было бы исчерпать весь объем книги. Ведь вече всегда выступало в качестве элемента, необходимого для реконструкции целостных систем - древнерусского общества, государс- 
твенным и спешит предложить читателю собственное. Твердо решив продемонстрировать «плохое знание украинской исследовательницей историографии», П. В. Аукин иллюстрирует свой тезис несколькими примерами. Среди них, напр., такой: при анализе летописных сообщений «о вечевых расправах» не учитывалась зарубежная историография относительно аналогичных явлений в Центральной и Восточной Европе (с. 405), и необходимо было бы привлечь хотя бы статью в Анджея В. Поппэ в: Słownik starożytności słowiańskich, t. IV, 251-252.

Замечание рецензента относится не к обзору историографии (в книге с. 8-16), а к разделу «Вечевой суд» (гл. 3, с. 301-306). Здесь анализируются сообщения о покараниях горожанами князей и «своей братьи»-горожан. «Расправы людей» известны, в самом деле, в Центральной и Восточной Европе, но не только. Для анализа огромного сравнительно-исторического материала потребовалась бы специальная монография, и, по всей видимости, не одна. К тому же, в этой тематике доводьно много спорных вопросов, и вряд ди имеет смыс пытаться решить одно неизвестное через другое. Соответственно, в книге я сознательно ограничивалась древнерусскими источниками (что ней и оговорено). Рецензент ссылается на статью в словаре. Словарные статьи, действительно, привлекались только в тех случаях, когда необходимо было уточнить значение слов, привести подсчеты частоты употребления, и т.п. Как правияо, считается, что привлечение или непривлечение статей из словарей и энциклопедий не может свидетельствовать о знакомстве или незнакомстве с историографией вопроса. Но достаточно примечательно то обстоятельство, что П. В. Аукин смешивает справочные статьи, имеющие свою специфику, и научную литературу.

Далее, комментируя выражение «немецкая школа права» рецензент воскдицает: «трудно поверить, но автор, по-видимому, не знает о немецкой «общинной» теории Г. А. Маурера и его последователей, оказавшей огромное вдияние на русскую историографию» (с. 405). Так сложилась, что русская историческая наука и смежные дисциплины во многом зависели от теорий, разработанных немецкими учеными. Однако уже в конце XIX в. это наследие было хотя бы отчасти освоено, и М. Ф. Владимирский-Буданов, напр., писал о «немецкой»

тва, общины, права. Даже решение многих, казалось бы, частных вопросов зачастую зависело от общих взглядов ученых на развитие общества. Соответственно, тема веча разрабатывалась или хотя бы упоминалась почти во всех работах, посвященных Древней Руси, и, как следствие, ее почти невозможно представить в полном объеме. Здесь придется ограничиться сравнительно кратким обзором». 
и «славянской школе». ${ }^{6}$ Кроме того, корректнее было бы говорить о Маурере как об основателе «теории марки» (для историка такие детали обычно важны).

П. В. Аукин пишет, что автор книги совершенно зря пытается опровергнуть тезис о владимиро-суздальском «самовластии», ведь он давно опровергнут А. Н. Насоновым и др. (с. 407). 7 Уважаемый колдега, к сожалению, недопонял, что на указанной им странице опровержений нет. В книге анализируются два рассказа об изгнании епископа Леона из Владимиро-Суздальской земли (Лавр. под 1164 г. и Ипат. под 1162 г.), и вначале излагается мнение исследователей по поводу каждой из версий этого летописного сообщения. На с. 141 сделаны две ссылки - пишется об ученых, опирающихся на Лавр. и об исследователях, опирающихся на Ипат. В обоих случаях перед указанием литературы сделана оговорка: «см., например...» ${ }^{8}$ (ее рецензент «не приметил»). Впрочем, вся 2-я глава посвящена анализу летописных версий в параляельных известиях, и чтобы это недопонять и не заметить, необходимо приложить значительные усилия. Поэтому не исключено, что П. В. Аукин не недопонимает, а сознательно прибегает к искажению содержания.

Ниже, еще раз обратившись к исследованиям А. Н. Насонова, рецензент упрекает меня в том, что исследование, противоречащее наблюдениям ученого о соотношении Ипат. и Лавр. за XII в., проведено в «труднодоступном издании», и, видимо, скорбя о «труднодоступности», ссылку на упомянутую статью не дает (с. 407). При этом, речь идет о периодическом издании: Palaeoslavica (Cambridge, Massachusetts) - на деле вполне доступном в крупных научных цен-

(6) В. Ф. ВлАдИМИРСКИЙ-БУдАНОв, Обзор истории русского права (КиевСанкт-Петербург, 1900) 7-8 и др. Название «славянской» получила теория, поддержанная славянофилами (ее также называли «школой общинного быта», противопоставдяя «школе родового быта»).

(7) «Так, Т. А. Вилкул успешно борется с ветряными мельницами, опровергая тезис ... (с. 141), забывая сообщить, что он давно был уже опровергнут А. Н. Насоновым, мнение которого впоследствии было неоднократно повторено (Ю. А. Аимоновым, И. Я. Фрояновым и др.)».

(8) Текст книги, касающийся версии Ипат., с. 141: «В частности, исследователи, использовавшие Ипат, основывали на этой версии вывод о “самовластии" Андрея и о начале нового периода истории в "молодом" княжестве» ${ }^{106}$

Прим. 106: «См. например: Рьъбаков Б. А. Киевская Русь. С. 550; Грушевський М. С. Історія України-Руси. Т. 2. С. 192. О том, что историки следуют схеме, предложенной летописцем, см. в: Приселков М.Д. История русского летописания (1940). С. 72-73». 
трах России 9 . За сим следует еще одна претензия: якобы автор «ни разу не приводит классических показателей вставок, типа текстологических швов...», а в сноске на с. 301 «грубо примитивизирует» мнение А. Н. Насонова. ${ }^{10}$ П. В. Аукин по какой-то причине не заметил доказательств в книге (на той же с. 141 (!), на с. 149, 165, 201, 204, 210, 212 и др.), ${ }^{11}$ а также недопонял, что на с. 201 (не 301, в рецензии описка) прим.310 речь идет отнюдь не об общей оценке исследований А. Н. Насонова. Здесь приводится мнение ученого относительно одного из фрагментов летописной статьи 1151 г. - а именно, описания пути и встречи полков Изяслава Мстиславича и Юрия Долгорукого «у Перепетовых». ${ }^{12}$ Кроме того, именно в этом месте приведены текстологические доказатедьства наличия в Ипат. вставки. В итоге,

(9) В Москве Palaeoslavica поступает в РГБ, ГИМ, ИНИОН, ИВИ, ИРЯ, Ин-т славяноведения РАН, РГГУ; в Санкт-Петербурге в РНБ, БАН, СПбГУ, редакцию журнала Вyzantinorossica. Интересно, что московский коллега помещает ремарку о «труднодоступности» и не указывает выходные данные статьи именно в параграфе «деконструкция историографии».

(10) «...вот как она передает его основную мысль: “А. Н. Насонов сравнивал тексты, но он считал Лавр. сокращением Ипат. (с. 301, сноска)... Но вот к какому выводу на самом деле пришел этот историк: «Несомненно также, что этот киевский летописный источник, хотя был очень близок к Ипатьевской летописи, однако несколько отличался от текста последней, представляя более раннюю редакцию и не имел вставок из черниговского источника". Таким образом, точка зрения А. Н. Насонова грубо примитивизируется, и на этом фоне расцветают достижения автора».

(11) Разумеется, в моей статье: Т. Вилкул, О происхождении общего текста Ипатьевской и Лаврентьевской летописи за ХІІ в. (предварительные заметки), Palaeoslavica 13.1 (2005) 21-80, фрагменты летописей анализируются более детально; приводится свыше 30 примеров текстуальной зависимости Ипат. от общего протографа, в целом вернее отраженного в Лавр. В книге, посвященной иному предмету, разбирать тексты стодь подробно было бы непозводительной роскошью, однако некоторые я постаралась рассмотреть. Часть из приведенных в книге примеров затрагивается ниже.

(12) Ср. текст книги, с. 201: «Одна из вставок разрывает фразу, благодаря разрыву возникают противоречия и грамматические несогласования. Действующие лица этой интерполяции - Вячеслав, Изяслав и Ростислав, в общем же с Лавр тексте присутствует один Изяслав. При переходе от одного блока текста к другому меняются формы множественного и единственного числа и создается неправильная грамматическая конструкция ${ }^{309}$. Эта и иные неувязки позволяют рассматривать тексты Лавр и Ипат не только как параллельные источники, но как первоначальную и вторичную версию ${ }^{310}$. 
строгие критические утверждения П. В. Аукина прямо противоречат содержанию рецензируемой им монографии.

Наконец, рецензент упрекает автора книги в незнакомстве с примером из монографии Б. Н. Флори относительно полоцкого пира 1158 г.: пир «называется точно так же («братчиной»), как и крестьянские общинные пиры, зафиксированные в делопроизводственной документации XVII в.» (с. 405-406). П. В. Аукину выгоднее было бы поместить это замечание в иной параграф - «Деконструкция лингвистики». Дело в том, что в своей оценке важности этого наблюдения рецензент разошелся во мнениях не только с автором рецензируемой им книги, но и с большинством лингвистов. Общеизвестно, что иексемы могут функционировать долгое время, изменяя при этом свое значение, и наличие одного и того же слова в ранних и поздних текстах вовсе не свидетельствует о тождественности явлений. Например, слово «посадникъ» применительно к новгородским реалиям XI в., когда так могли называть сына киевского князя, и применительно к реалиям даже не XIV-XV вв., а 2-й пол. XII-XIII вв. - обозначает разные понятия. Посадничество в XI в. и в XIII в. имеет разные функции. То же касается обозначения «тысяцкий» в Киеве в XI-XII вв. и в Новгороде в XIII в., и др.

Прим. 309: «“Изяслав же слышав то (так $\Lambda$, 'ту въсть' РА и АПС), поиде по нем, блюда того, дабы ся не сняль с Володимерком // и постиже

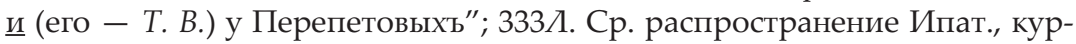
сивом выделен общий с Аавр текст: “Изяславъ же слышавь ту вюсть, поиде по Дюрги, блюда того, абы ся не сняль с Володимеромъ... Вячьславъ же и Изяславъ и Ростиславъ поклонившеся въ вторникъ святьи Богородици... Изяслав же съъхавъся с Вячеславомъ и съ ...Ростиславомъ, и тако угадавъше....а сами въсташа к Василеву... поидоша... и сташа полкы своими на ночь, $u$ постиже $u$ (его, но в этом контексте непонятно, кого, поскольку первая половина фразы написана за пол-диста до ее продолжения Т. В.) у Перепетовых"; 434И. Подробнее: Вилкул Т. А. О происхождении общего текста, $48-49$ ».

Прим. 310: «Дополнительный фрагмент Ипат как вторичная редакция до сих пор не рассматривался. А. Н. Насонов сравнивал тексты, но он считал Иавр сокращением Ипат: Насонов А. Н. История русского летописания. С. 94-95. Как правило, для анализа сюжета избирают более пространную версию Ипат, см. например: Грушевський М. С. Історія України-Руси. Т. 2. С. 29. Следует добавить, текст протографа лучше сохранился в Давр, но здесь также имеются следы редактирования. В последней фразе слова “бъ бо ему въсть” касаются Юрия, но его имя не названо, а вслед за этим описываются подвиги Андрея...» 


\section{По поводу «деконструкции текстодогии».}

Текстология дисциплина достаточно сложная, предполагает работу с текстами и, зачастую, высокий уровень гипотетичности построений. Уважаемый коллега начинает параграф с безапелляционного заявления:

«Текстодогические вопросы тоже решаются вполне "нетрадиционно". Рассказ о событиях 1015 г. в Новгороде НП Т. А. Вилкул, является "примером текстуальной зависимости от ПВ $\Lambda^{\prime \prime}$ (с. 29), хотя в первом есть очевидные лучшие чтения, а во втором - столь же очевидная вставка» (с. 409; здесь и далее подчеркнуто мною. - Т. В.).

На этом придется остановиться подробнее. П. В. Аукин предполагает решенной крайне сложную и запутанную проблему соотношения текстов ПВЛ и НП М мадшей редакции, связанную с еще более запутанной проблемой так называемого Начального свода. В своей недавней статье он попытался опровергнуть часть моих аргументов. ${ }^{13}$ На самом деле, однако, ни опровержения, ни доказательства в его работе отнюдь не «очевидны». ${ }^{14}$ В частности, здесь исследователь апел-

(13) Т. Вилкул, Новгородская первая летопись и Начальный свод, Palaeoslavica 11 (2003) 5-35; П. В. Аукин, События 1015 г. в Новгороде: К оценке достоверности летописных сообщений, Отечественная история (2007) № 4, 3-20.

(14) Покажу это на одном примере. Как известно, число славянских воинов Ярослава по ПВ $А-40000$, а по НП $А$ мл. - 4000, в 10 раз меньше. Я писала о том, что писцы могли как «увеличивать» численность войска, так и «уменьшать» его, и что вполне возможно, исходным является вариант ПВЛ. Примеры приводились из летописных сводов. П. В. Аукин заявил о том, что необратимых доказательств об уменьшении чисел нет (не смотря на то, что мною сравнивадись цифры в ПВА и поздних летописях - напр., Аьвовской, и, в том числе, уменьшение чисел в библейских цитатах, число жен Соломона 70 - вместо 700!). Исследователь утверждает также, что в Новгороде вместе с его округой вряд ли набралось бы 40000 воинов, а значит, исходя из таких, «рациональных» соображений, необходимо предполагать, что первоначальный вариант в НП (Дукин, События..., 13). Прежде всего, писцы действительно могли уменьшать числа. Даже не обращаясь вновь к поздним сводам. Ср. пример из Александрии Хронографической, для которой мы имеем контрольный текст греческих списков, что искдючает какие-либо сомнения. Александрия кн. 1, гл. 41, Иудейский хронограф (Архивский и Виленский списки): «пльнникъ же

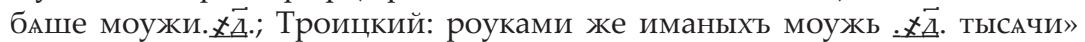

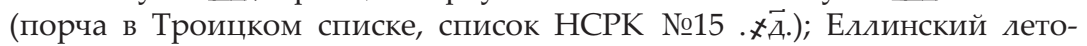


иирует к такому показателю, как вставка и, шире, непротиворечивость издожения, и к «лучшим» чтениям. Апелляция весьма сомнительная. Книжники, работавшие в период позднего средневековья и имевшие большой опыт работы с компиляциями, могли не только «наращивать», но и устранять противоречия, делая издожение более внятным и «рациональным». ${ }^{15} \mathrm{~K}$ тому же, определение вста-

писец 1-й редакции: «и план'никь же бАше моужии .у..» (во 2-й редакции контаминация, но число сохранено: «а пльнникь же бяше мужии, руками изыманых, 400»; см. Летописеи, Еллинский и Римский, т. 1 (Мос-

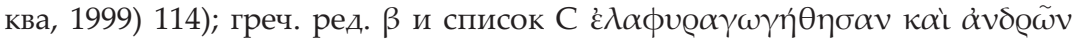

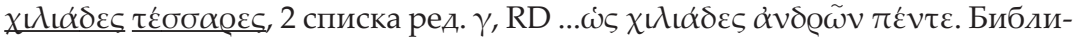
ографические справки см. в: Т. Вилкул, Александрия Хронографическая в Троицком хронографе, Palaeoslavica 16.1 (2008) 103-117. Далее, известно, что «рациональные» соображения в древних описаниях битв, особенно связанных с агиографической тематикой (а сюжеты ПВ $И$ и НП $А$ мл. входят в борисо-глебский цикл, о чем необходимо помнить) недействительны. О символике чисел в древнерусской письменности уже накопилась значительная дитература, П. В. Аукин мог бы обратиться, напр., к книге В. М. Кириллина, посвященной этой теме, и лекциям И. Н. Данилевского. См.: В. М. Кириллин, Символика чисел в литературе Аревней Руси (СанктПетербург, 2000); И. Н. ДАнилевский, Русские земли глазали современников и потомков. IX-XII вв. (Москва, 2000) 226-228. В данном случае, может быть, моделью для составителя послужило описание войска Соломона: «БАше

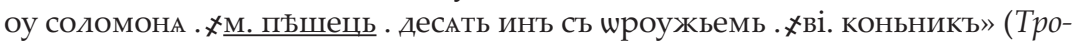
ицкий хронограф, л. 120а, цитируется 3 Цар. 4.26; шроужие - здесь означает 'колесница'). Ср. также Песнь Деборы, Троицкий хронограф, л. 25b, Ис. Нав. 5.8 «аще явиться праща . въ .мे. тысящахъ». Может быть, однако, права Н. Н. Невзорова, предположившая, что исходным является чтение Паримейника, где общее число воинов Ярослава - 36 тысяч. Исследовательница обратила внимание на то, что число 36 имело символическое значение в древнееврейском, в толкованиях оно обозначало 'праведник'. Н. Н. НевзоровА, «Старая» борисоглебская проблема в «новом» свете Паримийных чтений, в: Древнерусское духовное наследие в Сибири: научное изучение памятниов традицинной русской книжности на востоке России, т. 2 (Новосибирск, 2008) 113-124. Следует, видимо, обратить внимание на то, что и в паримейных чтениях, и в ПВЛ называются десятки тысяч, а не тысячи. В любом случае, обращение П. В. Аукина в таком сюжете к соображениям здравого смысла свидетельствует не только о крайне упрощенных, но о принципиально неверных представлениях.

(15) См., напр.: Е. Г. ВодОлАзкин, О Толковой Палее, Златой Матице и «естественнонаучных» компиляциях, ТОДРА 51 (1999) 89; ОН жЕ, Всемирная история в литературе Древней Руси (Санкт-Петербург, 2008) 267 и др. Еще один прием П. В. Аукина, вызывающий сомнения: при определении ранних и поздних чтений он оперирует таким понятием, как «по- 
вок отличается чрезвычайно большой степенью гипотетичности, в этом ошибались даже филологи высочайшего класса. То же касается «лучших», «архаичных» и «трудных» чтений. ${ }^{16}$ Следует принять во внимание то, что в НП $\Lambda$, по-видимому, использованы палейные тексты $^{17}$ и, в целом, книжникам XIV-XV вв. были доступны весьма архаичные по языку памятники, часто служившие образцом. ${ }^{18}$ Вдум-

нятность» сообщения летописи и распространение «понятных» чтений в поздних яетописных сводах (Дукин, События..., 11). Что текстологически неоправданно, ибо первоначадьные чтения часто содержат, наоборот, «непонятные» и «трудные» варианты. Кстати, когда у него возникает потребность, он со столь же прямолинейной настойчивостью использует аргумент lectio difficilior (там же, 15).

(16) Ср., напр., о правиле lectio difficilior: Э. Тов, Текстология Ветхого Завета (Москва, 2001) 281, 288-289.

(17) Т. А. Вилкул, О начальных датировках «Начадьного свода». Доклад (22.10) на международной конференции «Повесть временных лет и начальное летописание, посвященной 100-летию выхода книги А. А. Шахматова «Разыскания о древнейших русских летописных сводах», проходившей в Москве, 22-25 октября 2008 г. Несмотря на то, что палеи создавались в XIII-XV вв., в их составе видим архаические древнеславянские переводы. Об одном из сюжетов Толковой палеи и зависимости ее от ПВ см.: Т. А. Вилкул, Толковая Палея и Повесть временных лет. Сюжет о «разделении язык», Ruthenica VI (2007) 37-85 (Интернет-версия: http:// www.history.org.ua/index.php?urlcrnt=ruthenica/index.php\&numnam=6). Создание Полной хронографической палеи Е. Г. Водолазкин относит к рубежу XIV-XV вв. Е. Г. ВодолАзкин, Новое о палеях (некоторые итоги и перспективы изучения палейных текстов), Русская литература (2007) № 1, 3-23.

(18) В частности, П. В. Аукин уповает на первоначальность выражения «вои славны тысяща» (Дукин, События..., 9, 15). Однако ничто не показывает, что это уникальное выражение восходит к тексту более раннему, чем создание ПВ $\Lambda$, а не сконструировано новгородским книжником из имеющегося материала. В хронографической литературе и ветхозаветных книгах масса упоминаний «тысящь» и «тысящников», реже, но встречаются «славные». Относительно последнего обозначения ср. Виленский хронограф, л. 205об., Ис. Нав. 4.4: «и призва йс .ві. моужь славенъ от сйовъ ийлевъ единъ»; Троицุкий хронограф, л. 57а, 1 Цар. 9.6: «и ре ет отрокъ его . се зде ч $\overrightarrow{\lambda в к ъ ~ б ж ̈ и и ~ в ъ ~ г р а д ъ ~ с е м ь ~ . ~ ч ~}$ «От трии тъхъ славенъ»; л. 272b, Дан. 14.2: «Въ вавилонъ же бъяше даниль жизньникъ . съ ц`рмь коуромь славенъ . паче дроугъ его». См. также об Александре Македонском, Ам. 200.1-2: «призва славныя своя, с ними ж въспитася, и раздъди имъ цсртво и оумре». П. В. Аукин пишет о том, что «нарочитые» ПВ $А$ не является «terminus technicus», но «вои славны тыся- 
чивые писцы в иных случаях восстанавдивали даже испорченные названия и имена ${ }^{19}$. Ни одного необратимого доказательства в статье

ща» тем более им не является. Ср. хотя бы массу усилий, потраченную исследователями на то, чтобы выяснить значение выражения.

(19) Приведу, снова-таки, одно из чтений редакций Александрии Хронографической. Этот памятник удобен тем, что имеется контродьный текст греческих списков, и сохранился в разных редакциях. Соответственно, первоначальные чтения обычно реконструируются надежно. В приведенном ниже примере восстановлено имя персидского царя Ксеркса, широко известное из хронографической литературы. В разных списках: Архивский хронограф «кръксови», Виленский «керьксови», Елдинский летописец 2-й редакции «Керъксови» (в одном из списков, однако, угадано правильное: «Ксеръксови»), Троицкий список - «ксероксови». См.: Александрия, книга 3, глава 28; Арх. л. 340; Вил. л. 494; Тр. ^. 334d; Аетописец, Елхинский и Римский, т. 1 (Москва, 1999) 173. Наиболее далеко разошедшиеся (из ранних) редакции Иудейского хронографа и Едлинского летописца 2-й редакции дают схожие чтения, т. е. исходным, видимо, было ошибочное «Керъксови» (и, в любом случае, в архетипе Еллинского-2 несомненно читалось «Керъксови»). В одном из списков Елдинского-2 и, по-видимому, в Троицком имя было восстановлено. В некоторых случаях, конечно, идентификация могла быть ошибочной. Напр., в той же Александрии имя Набонассара («Навънасоръ») несколькими писцами независимо один от другого было восстановлено в «Навуходоносоръ». Т. е., в общем случае, если название было узнаваемо, ошибку книжники могли попытаться исправить. Тем временем, относительно сюжета 1015-1016 (1015-1019 по ПВ А) в НП А м и и ПВ А один из пунктов, по которым мнения исследователей расходятся - исходное написание наименования «Рокомъ»/«Ракомъ» в летописях. П. В. Аукин считает, что «шедъ на Рокомъ» ПВ И испорченное чтение, и аутентично «съдъ на РакомЂ» НПЛ мл. ред., поскольку в документах XV в. село вблизи Новгорода называется «Ракома» (Дукин, События..., 13). Почему исследователь считает, что «Ракома» XV в. должна свидетельствовать не о том, что именно в такой форме название было известно позднему книжнику, и тот в соответствии со своими знаниями приспособил текст летописи, а о том, что в писцовой книге XV в. отразилась форма, более древняя, чем известная из ПВ тах обычна. В том числе, в переводных памятниках в ранних редакциях встречаются такие чтения как Сарданаполь и т. п. Между прочим, если поздние известия имеют преференции, может быть следует читать не «Содко», как в НП 1 мл, а «Садко», и не «Олександръ», а «Александръ»? Ср. иные примеры изменения названия. В Киевском своде в одной из годовых статей сер. XII в. о поселении говорится: «от Буличь», ПСР 1, т. 2, стб. 518, более позднее и современное название - «Бъдичи» / Беличи. «Жълянь» изменилось в «Жуляны», и т.д. 
П. В. Аукина нет, т.е. с утверждением об «очевидности» исследователь поспешил.

Далее рецензент пишет об «абсурдности», применительно к 1147 г. писать о том, что Ростислав Мстиславич смоленский распоряжался смодьнянами и новгородцами. И что достаточно «просто открыть летопись» и убедиться в обратном: киевский князь Изяслав предлагал брату «нарядить» на войну «кроме новгородцев, еще и смольнян» жителей земли, где он сам княжил (с. 409). Снова сталкиваемся с категоричностью утверждения П. В. Аукина, дополненной здесь еще необычайной «простотой» предлагаемых им текстологических процедур. Рецензент, возможно, знает, что в 1147 г. в Новгороде сидел Святополк Мстиславич, а далее его сменил сын Изяслава. Предложение «наряжать» людей чужого князя (Святополк, между прочим, был старше Ростислава) выглядит странно, и такому явлению необходимо искать объяснение. Может быть, П. В. Аукин подозревает и о том, что при рассмотрении исторических событий сер. XII в. следует тщательно анадизировать текст Киевского свода, редактированного в пользу Ростислава Мстиславича, ${ }^{20}$ а также сопоставлять его с известиями НПЛ и Лавр. ${ }^{21}$ В данном случае, несколько увлекшись, он, видимо, упустил это из виду.

(20) В литературе отмечались случаи, когда в перечислениях Ростислав поставлен перед киевским князем Изяславом, его роль неоправданно преувеличена (в моей книге прим. 55 на с. 33). Примеры позднего редактирования свидетельствуют о вмешательстве в текст составителя Киевского свода (создан на рубеже XII-XIII или в начале XIII в.), а он настойчиво пытался создать видимость идеального соправления Изяслава, Ростислава и их дяди Вячеслава Володимирича.

(21) Известно, что Изяслав Мстиславич обращался к брату Ростиславу с такими речами (1147 г.): «а тамо наряди новгородци . и смодняны ать оудержать Гюргя», «а тамо оу тебе смодняне и новгородци». См.: ПСР, , т. 2, стб. 347, 359. При этом Ростислав появился на новгородском столе лишь в 1154 г., сместив Ярослава Изяславича. В том же 1154 г., по-видимому, велась подготовка к новой серьезной войне между Изяславом Мстиславичем и Юрием Долгоруким, но внезапно Изяслав умер, и события повернулись иначе. Судя по всему, произошла перестройка коалиций, и Ростислав стал врагом своего родного брата (и это выразилось, в том числе, в занятии им новгородского стола), тогда как Святополк Изяслава не предавал, несмотря на некоторые трения между ними. Согласно НП $\lambda$, Ярослава «выгнали» новгородцы в марте 1154 г., а в апреле в Новгороде утвердился Ростислав Мстиславич. При этом, Изяслав Мстиславич умер в ноябре (мартовского) года. Ср. НП Л с. 29, ПСР А. Т. 1, стб. 341-342, Т. 2, стб. 468-469. В начале года на помощь себе Изяслав Мстиславич позвал именно Святополка. По моим наблюдениям, «изгнания» и «призвания» 
Но следующий пассаж глубокоуважаемого колиеги может поставить в совершенное затруднение. П. В. Аукин всесторонне исследует окончание примечания 424 на с. 103 рецензируемой им монографии и обвиняет меня в том, что, квалифицируя известие МЛС о созыве Всеволодом Юрьевичем в 1211 г. «т.н. собора» как позднее, я опираюсь исключительно «на мнение А. Е. Преснякова», которое «не имеет ценности», ибо было высказано «до основополагающих открытий в области текстологии».22 В частности, не учтено предположение А. Н. Насонова о том, что это известие из свода Юрия Всеволодича, и что писать о «поздней практике» нельзя, ибо первые соборы относятся к XVI в. (с. 410). Для ясности, приведу текст книги, с. 103 прим. 424 («историк» - речь идет о В. Т. Пашуто):

«В большинстве текстов, которые историк предлагал рассматривать как доказательство существования "собора", это слово отсутствует, ${ }^{424}$ а в одном случае он неверно определил значение».

${ }^{424}$ Отсутствует, в том числе, в описании завещания Всеволода Юрьевича 1211 г. по М/С, на которое во многом опирался исследователь: «Князь же великы Всеволод созва всъх бояръ своихъ с городовъ и сь водостеи, епископа Иоана, и игумены, и попы, и купцъ, и дворяны и вси люди, и да сыну своему Юрью Володимерь по собъ, и води всъх къ кресту, и цъдоваша вси дюдие на Юрьи». ПСР А. Т. 25. С. 108. Кстати сказать, о созыве разных чинов нет в $A$ и Сим-Тр под 1211-1212 гг., нет в $А П С$, а также в поздних сводах Новгородско-Софийской группы и Детописи Авраамки. Данное сообщение помещают лишь своды, зависимые от М/С: Воскресенская летопись, Тверской сборник и др. О позднем происхождении известия: Пресняков А. Е. Княжое право. С. 150-151, прим. 3. Несомненно, перед нами сочинение московского книжника, бравшего за образец современную ему практику.

князей, в том числе, в Новгороде часто были тесно связаны с подитикой князей и соотношением подитических сил в раздичных коалициях, и мою аргументацию рецензент не смог опровергнуть. Кроме книги, этот тезис обосновывается также в: Т. А. Вилкул, Новгородцы и русские князья в летописании XII века, Russia Mediaevalis X.1 (2001) 34-54. Относительно редактирования летописных статей сер. XII в. см.: ОНА жЕ, О происхождении общего текста..., 38-58.

(22) «Аргумента два: ссылка на мнение А. Е. Преснякова и заявление о том, что “несомненно, перед нами сочинение московского книжника, бравшего за образец современную ему практику” (с. 103, сноска)» (подчеркнуто мною. - Т. В.). 
Увы, рассуждения П. В. Лукина о земских соборах не имеют отношения к рассматриваемым проблемам, ибо в известии 1211 г. в МЛС слово «соборъ» отсутствует. В книге речь идет о том, что В. Т. Пашуто, постулируя наличие на Руси «собора», привлекал известия, где слова «соборъ» нет, ${ }^{23}$ в том числе, известие МЛС 1211 г. Утверждение о позднем происхождении этого фрагмента опирается не на «ссылку на мнение А. Е. Преснякова», а на тот факт, что известие отсутствует в ряде летописей, ${ }^{24}$ в том числе, в ранних летописных сводах;; работа А. Е. Преснякова отмечена потому, что именно этот исследователь заострил внимание на позднем происхождении известия. Что касается гипотез А. Н. Насонова о наличии в поздних

(23) В ранних летописных сводах слово «съборъ» употребляется единственный раз, в Киевском своде под 1147 г., в Ипат., где его появление вызвано, судя по всему, исподьзованием евангельских мотивов. Мучительная смерть князя Игоря Ольговича от рук киевлян уподоблена смерти Христа. В другом случае, в известии 1187 г., В. Т. Пашуто неверно определил значение слова в выражении «и съборы и монастыри». Разумеется, в переводных памятниках значение слова «сьборъ» более широкое, но В. Т. Пашуто опирался на летописи. Например, в 5-й книге Хроники Иоанна Малалы выражение «и съшедшеса на съборъ» является переводом греческого каі

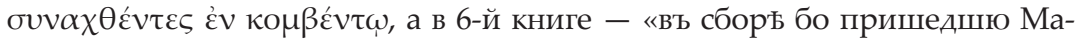

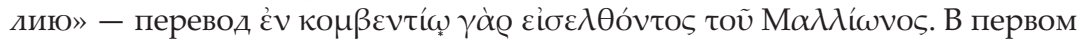
случае подразумевается собрание ахейских воинов, на котором было принято решение наказать Ахилла и лишить его возможности участвовать в войне, во втором - сюжет осуждения Манлия римскими «боярами». Cм.: H.-G. Bech, A. Kambylis, R. Keydell (eds.), Ioannis Malalae, Chronographia (Berolini: Novi Eboraci, 2000) (CFHB, 35) 75, 140. Но словоупотребление летописей в данном случае резко отличается от словоупотребления переводных текстов (в том числе - от древнеболгарского, как считают, перевода Хроники Малалы), что также отмечено в моей книге.

(24) В Лаврентьевской, Симеоновской и Троицкой (как она реконструируется) летописях, Детописце Переяславля-Суздальского, сводах Новгородско-Софийской группы и в Детописи Авраамки. Имеется оно тодько в сводах, зависимых от МАС. Полагаю, приведенный ряд летописей репрезентативен.

(25) Если рассматривать более детально, выходя за рамки монографического исследования, можно было бы отметить также то обстоятельство, что известие 1211 г. отсутствует, прежде всего, в ранних сводах (Даврентьевской летописи, Летописце Переяславля-Суздальского, НП $)$ ). При том, что НП, , по-видимому, пополнялась во Владимире во время пребывания здесь архиепископа Митрофана (1210-е гг.). Т. В. Гимон, Новгородское летописание первой четверти XIII в.: хронология и процесс пополнения летописи, в: Средневековая Русь, вып. 6 (Москва, 2006) 103. 
московских сводах фрагментов владимиро-суздальских и киевских сводов XII-XIII вв., не дошедших до нас, то это крайне дискуссионная проблема, ${ }^{26}$ и вводить рассмотрение дискуссионного вопроса, имеющего косвенное отношение к теме исследования, в окончание прим. 424 было бы вряд ли оправданным. Итак, на упреки П. В. Лукина ответить затруднительно, ибо коллега никак не объясняет, почему отсутствие известия 1211 г. в большинстве летописей он не зачислил в разряд аргументов, и по какой причине он считает, что в МАС упоминается «т.н. собор», когда этого слова там нет. (Следование мнению В. Т. Пашуто, а также торжественные размышления о «земских соборах Российского государства» вряд ди могут оправдать удивительный пассаж рецензента.)

Но вот, наконец, П. В. Аукин приводит суждение, которое в самом деле может послужить «деконструкции текстологии». По поводу одного из предполагаемых автором монографии заимствований он восклицает:

«Но ведь фразы-то разные! Если бы вторая, действительно, была «образцом» для первой... то летописец более позднего времени просто переписал бы ее из более раннего текста и обе фразы полностью бы совпади» (с. 412).

(26) В целом, летописеведы делятся на тех, кто считает, что в поздних летописях сохранидись фрагменты ранних сводов, и тех, кто полагает, что поздние сводчики могди «творить» историю при помощи комбинирования имевшихся в их распоряжении источников, и, так сказать, дописывать их. Оба «лагеря» имеют свои аргументы, я принадлежу ко второму. Однако для обсуждения этих проблем, в самом деле, необходимы специальные текстологические исследования. Следует добавить, что далеко не все наблюдения и не все подходы замечательного российского летописеведа, работавшего в середине XX в. (книга А. Н. Насонова была издана посмертно, в 1969 г.) были приняты в позднейших исследованиях. В частности, А. Н. Насонов часто считал критерием первичности и древности летописных записей их пространность. Поэтому, кстати, он положил в основу издания НП 1 младшего извода наиболее удаленный от протографа, но наиболее «полный» Комиссионный список, а также считал возможным привлекать версии весьма поздних летописцев - Устюжского, Архангелогородского и пр., о чем уже писал, напр., Донадьд Островски: D. Osтrowsкi, Introduction, в: IDEм (ed.), The Povest' vremennykh let: An Interlinear Collation and Paradosis (Cambridge, Mass., 2003) (Harvard Library of Early Ukrainian Literature. Texts, X.1-3) LI; D. Ostrowski, The Ideal Prince for the Times: Alexander Nevskii in Rus' Literature: Mari Isiaho, The Image of Alexander Nevskiy in Medieval Russia: Warrior and Saint (Leiden, 2006), Palaeoslavica XVI.2 (2008) 265. 
Такое «простое» представление о способах работы летописца и о введении заимствований из источников в корне неверно. Детописцы могли включать буквальные заимствования, а могди вводить парафразы, подчас цитировади точно, а подчас существенно изменяли текст, заимствовали крупными блоками или интерполировали небольшие включения. На материале библейских аллюзий это в последнее время было хорошо показано И. Н. Данилевским ${ }^{27}$, а в целом наличие раздичных способов работы книжников с источниками общепризнано в научной литературе ${ }^{28}$. Для наглядности, приведу в качестве примера заимствование из «Истории иудейской войны» в Киевском своде, отмеченное А. С. Орловым и Н. А. Мещерским. Ср. тексты, подчеркиваю не сближения, как это обычно делается в подобных случаях, а расхождения, дабы обратить внимание на то, что книжники не всегда «просто переписывали» фразы:

\begin{tabular}{|l|l|}
\hline Ипатьевская летопись & «История Иудейской войны» \\
и ту бъ видити ломъ копииныи. & И бысть видьти ломъ копьиныи \\
и звукъ оружьиныи & $\underline{\text { и скръжетание мечное, и щиты }}$ \\
\hline
\end{tabular}

\section{По поводу «деконструкции церковной письменности».}

В начале этого параграфа рецензент делает несколько полезных замечаний корректорского плана. Однако серьезные упреки рецензента вызывают, по меньшей мере, недоумение. В частности, он пытается уличить в непонимании древнеславянского текста, не зная самого древнеславянского текста, и привлекая лишь русский перевод (!).

Анализируя эпизод из Деяний апостолов (с. 413-414) П. В. Аукин, возражая против моей интерпретации фрагмента древнеславянского текста, прямо признается в том, что он привлекает текст «русского перевода». ${ }^{29}$ Рецензент не может не знать о том, что привлечение

(27) И. Н. ДАнилввский, Повесть временных лет. Герменевтические основы изучения летописных текстов (Москва, 2004).

(28) Не только летописцев. О том, что в творениях отцов церкви Священное Писание не всегда передано буквально см., напр.: М. Мецгер Брюс, Текстология Нового Завета. Рукописная традиция, возникновение искажений и реконструкций оригинала (Москва, 1996) 87 (перевод работы, впервые вышедшей на английском языке в 1964 г.).

(29) Эти суждения достойны того, чтобы привести обширную цитату из рецензии: «Действительно, если мы откроем русский перевод Нового Завета, увидим, что там написано следующее: “Ведь дия всех афинян и 
русского перевода при анализе древнеславянских памятников и, в особенности, при проверке интерпретаций, некорректно, ${ }^{30}$ но для него, вероятно, древнеславянский текст был «труднодоступен». Цитируемый фрагмент Деяний рецензент называет «элементарным». Уважаемый коллега ошибается. В ДА 17.21-22 читается следующее (в книге цитата была приведена с купюрами, выделяю опущенные в ней сегменты курсивом): «...страньныи . ни вь что же ино праздны бюахоу глати . или и сльшиати что новюю. Став же Павел посре Ариюва леда ре $^{4}$ моужи атиньисции по всему гко хоудожаишею вы вижљю» ${ }^{31}$. Текст этот отнюдь не «элементарен», и даже, смею утверждать, достаточно сложен. В подобных случаях, как правило, славянские читатели и писцы ориентировались на «ключевые» слова, опуская «темные» места. Из древнеславянского текста неясно, что в первой фразе речь идет о жителях Афин, а во второй - о собрании в Ареопаге. Тем более, что даже перевод последнего слова неверен - «Ариевъ ледъ». Т.е. после прочтения этого отрывка Апостола для древнерусского книжника вполне естественным был вывод о том, что в Ареопаге собирались «вси афинее», и что они же обозначались как «мужие афинеистии». Современного русского перевода книжники, в том числе летописцы, знать не могли.

иностранцев, живущих в городе, нет большего развлечения, чем узнавать и обсуждать все новейшие идеи. Павел, представ перед Ареопагом, заговорил" (Деян. 17.21-22). Ясно, что, на самом деле, “все афиняне" - это просто жители Афин, и к членам Ареопага они никакого отношения не имеют. Но откуда же взялась “интерпретация" Т. А. Вилкул? Выясняется, что ее основой послужил славянский перевод Апостола [в самом деле, работать необходимо исключительно с русским Синодальным переводом, ни в коем случае не с древнеславянским. - Т. В.], который автор цитирует следующим образом: “Афинее же вси приходяще и страннии (все афинские граждане и неафиняне. - Т. В.)... став же Павел посредъ Ариева леда рече мужие афинеистии". Таким образом, Т. А. Вилкул, вопервых, не поняла элементарного славянского текста, а, во-вторых, повидимому, незнакома с содержанием Деяний апостолов».

(30) Славянские книжники имели более ограниченные ресурсы, нежели переводчики Нового и Новейшего времени. Они часто применяли технику пословного перевода, сохраняя синтаксис оригинала и кадькируя лексику; в иных случаях без привлечения греческого текста смысл переводных текстов вообще понять невозможно.

(31) Так в сербском Матичином Апостоле; в македонском Струмицком: «...страны : илі глати чесо : слишати новое : став же Павель посрь ${ }^{A}$ ариева леда ре ${ }^{\Psi}$ мАжие афинести : по вспмя пюко хАдожаиии ви виж А». 
Ниже, рецензент возражает против утверждения, что избиение 70 братьев приписано сначала самому Авимелеху, а затем «мужам», принявшим его на царство. Он утверждает, что если бы автор проанализировала весь «рассказ полностью», то поняла бы, что Авимелех совершил убийство с «праздными и своевольными людьми», «которые и были сихемскими мужами» (с. 414). 3десь П. В. Аукин снова обращается к русскому переводу ${ }^{32}$, более того, к его небольшому отрывку, а не к «рассказу полностью», анализ всего фрагмента Суд. 9.1-18 не мог бы послужить подобным выводам. В тексте Синодадьного перевода отмечу только: Суд. 9.3. «братья матери его внушили о нем все сии слова жителям Сихемским и склонилось сердце их к Авимелеху, ибо говорили они: он брат наш. 9.4. И дали ему семьдесят /сиклей/ серебра из дома Ваалверифа; Авимелех нанял на оные праздных и своеводьных людей, которые и пошли за ним. 9.5. И пришел он в дом отца своего в Офру и убил братьев... (обращается $\kappa$ «мужам сихемским», собравщился для процедуры поставления на изарство оставщийя в живых младший сын Гедеона) 9.18. а вы теперь восстали против дома отца моего, и убили семьдесят сынов отца моего...» ${ }^{33}$ Древнеславянский текст Суд. 9.1-7,16-18 категорически препятствует тодкованию П. В. Аукина. Ср. особенно: «9.3. и глаша брата мт̈ри его ш немъ . въ

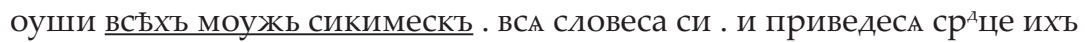
въслъдъ Авимелеха ... 9.4. и даша .о. сребра $\bar{w}$ домоу Ваальверефъ завътоу . и нага ими Авимедехъ мужь тысащю . не богщеса (в другом списке: моужа тоща и богщас; «тоща» - по-видимому, исходный вариант, перевод, кеvoù , «и» порча вм. «не»)...» ${ }^{34}$

(32) На сей раз об этом не заявлено прямо, но о том свидетельствует приведенная им цитата.

(33) То же в соответствующем месте Септуагинты: 9.3 к $\alpha \dot{\imath} \dot{\varepsilon} \lambda \alpha \lambda \eta \sigma \alpha \nu$

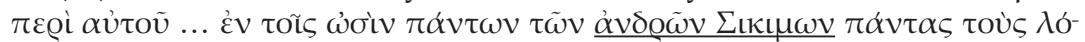

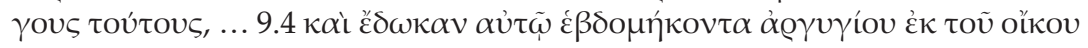

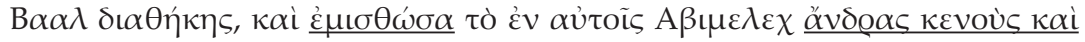

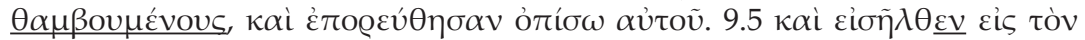

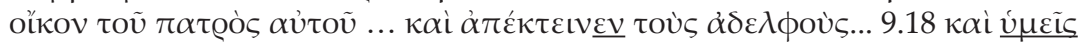

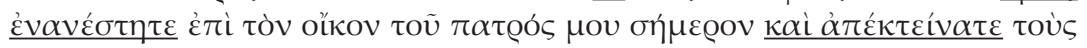

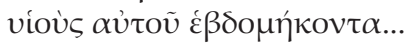

(34) Для оценки «рассказа полностью» привожу фрагмент Суд. 9.1-7,16-18, согласно тексту Троицкого хронографа XIV в., л. 30с-31а (близкие чтения - в Полной хронографической палее); с некоторыми разночтениями по списку Виленского хронографа (далее: Вил) 1-й пол. XVI в. (один из списков Иудейского хронографа 2-й пол. XIII в.), л. 229об., а также Острожской Библии. «(Суд. 9.1) И иде Авимелехъ къ сномъ Ие-

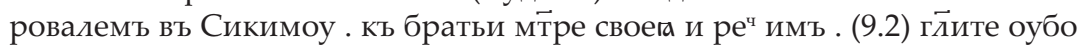


Из текста ясно, что Авимелех совершил убийство с наемниками, которых нельзя отождествлять с «мужами сикимскими». Одни и те же действия, как видим, действительно приписываются Авимелеху и «мужам сикимским», и выводы, сделанные в книге, опирались на корректное прочтение. В итоге: П. В. Аукин неверно прочитывает русский текст, при этом обвиняя в ошибке прочтения (в древнеславянском тексте) автора. Возможно, в книге было слишком кратко сказано об этом, но в общем кажется достаточно очевидным, что специалисты по древнерусской проблематике обычно пользуются древнеславянскими переводами Библии.

Пара «мелочей в придачу». На с. 414 рецензент пишет о том, что в книге (с. 143) неверно трактуется то, что ростовский епископ якобы «запрещает праздновать в великие праздники», тогда как на деле речь шла о необходимости поста на Рождество или Крещение Господни». Но на с. 143 моей книги приводится цитата из летописи и читается буквально следующее: «...(Деон) велел «не ъсти мясъ» на великие церковные праздники: «ни на Рожьство Господне, ни на Крещенье», то есть нарушил даже достаточно суровую константиноподьскую практику постов». Поскольку на с. 142 приведены обширные фрагменты Лавр и Ипат, я не стала повторять о посте по средам и пятницам (в

въ оуши моужемъ сикимьскомь . кое добръе вамъ . ежели владъти вами .о. моужь . всъмъ сНноъ Иеровалемъ . или владъти моужоу единомоу . и помАнете гако кость ваша и плоть ваша есмь азъ . (9.3) и гл̆аша бра мтри его ш немъ . въ оуши всьхъ моужь сикимескъ . вса словеса си . и

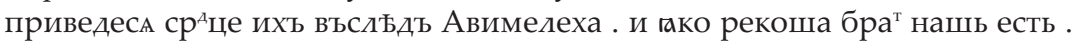
(9.4) и даша .‥ сребра $\bar{w}$ домоу Ваальверефъ завътоу . и нага ими Авимедехъ мужь тысащю . не богаеса /Вил моужа тоща и богща', Острожск. м४жевъ младыхъ и льпыхъ/ . и идоша въсльдъ его . (9.5) и приведе и / Вил Острожск прииде/ в домъ $\vec{w}^{\mathrm{T}} ц$ своего . въ ефрать . и изби братью

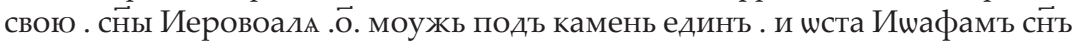
Ишроваль мнии . гако ск и весь домъ Алонь . и шедъше цсрьствиша Авимелеха . оу ВаланА станоу иже въ Сикимъхъ . (9.7) и повъдаша Ишафамоу . и шедъ ста на верхоу горы Газиринъ . и въздвиже глас свои . и възвавъ ре мене моужи сикимьстии . и да ва ${ }^{c}$ оуслышить б̈ъ ... (9.16) И нынъ аще поистинъ . и по свершенью створисте . и цр сьствисте Авимелеха . и аще есте добростворили . сь Ишровелемъ . и 3 домомь его . по ш̈данию роукы

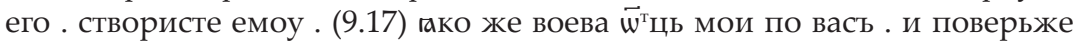
дшю свою въ страноу . и ш̄та васъ ш̄ роукы МадиамлА . (9.18) вы же въста-

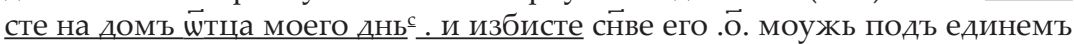
каменемъ /Вил доб.: и цр ${ }^{\mathrm{c}}$ твовасте авимелеха, Острожск и постависте црем' авимелеха/ . сн̈ъ женимыи его надъ моужи сикимьски . гко братъ вашь ес ${ }^{\mathrm{T}} \gg$. 
Лавр - «в среды и в пяткы», с. 142, левая колонка табл.), предполагая, что читатели понимают язык летописи и могут сами сопоставить тексты.

На с. 114-115 рецензент пишет о том, что ему «непонятно, на каком основании делается вывод о том, что в словах пророка Исаии о «князьях содомских» и «дюдях гоморских» идет речь о «группах дюдей равного статуса». Если необходимы пояснения - в книге приводится цитата из Паримейника (Ис. 1:6) относительно известного библейского сюжета о разрушении Содома и Гоморры. Господь через пророка обращается к «князьям содомским» и «Дюдям гоморским». Как правило, не предполагают, что в Содоме жили только «князья», а в Гоморре - исключительно «дюди», или что «князья» или «дюди» по отдельности вызвали гнев Господень (города были уничтожены полностью).

\section{По поводу «деконструкции дингвистики».}

В этом параграфе в поправках уважаемого коллеги встречаются погрешности. П. В. Аукин, возражая против отнесения слова «прбтити» к редкой книжной яексике, пишет о том, что глаго «присутствует в говорах» (с. 419). Этот довод не доказывает некнижного происхождения. Вокабуляр народных говоров формировался, в том числе, за счет книжной лексики и, в том числе, на достаточно позднем этапе развития церковно-славянского языка. Подобные заимствования в народные говоры - одна из тем дингвистических исследовательских разработок. О том, что «претить» заимствовано из церковно-славянского см. у Фасмера. ${ }^{35}$

Делая замечание относительно дательного самостоятельного в тексте из Галицко-Волынской летописи «Самому же Данилу созвавшу въче, оставьшуся вь 18 отрокъ върнихъ и с Дъмьяномъ тысяцкымъ своимъ, и рече имъ...» (с. 418), рецензент несколько сокращает цитату, забывает уведомить читателя, что речь идет о таком значении слова «въче» как 'совет' и что в работе обсуждаются возможные интерпретации и мнения, высказанные в научной дитературе. ${ }^{36}$ Если

(35) М. ФАСмеР, Этимологический словарь русского языка, т. ІІІ (Москва, 21987) 361.

(36) Текст книги, с. 25: «Значение 'совет' вполне удовлетворительно и экономно объясняет контекст без необходимости прибегать к домыслам. В том же ряду стоит и необычайно малочисленное галицкое собрание, в составе которого названы тысяцкий и 18 отроков ${ }^{27}$ ».

Прим. 27: «"Самому же Данилу созвавшу въче, оставьшуся вь 18 отрокъ върнихъ и с Дъмьяномъ тысяцкымъ своимъ, и рече имъ...", 763И. 
же не пытаться подменить сказанное в книге иными суждениями, окажется, что дательный самостоятельный не может препятствовать предложенной интерпретации. ${ }^{37}$ Помимо всего прочего, при анализе текста Галицко-Волынской летописи необходимо учитывать то, что ее составитель или составители пытались имитировать текст своих источников (в том числе, хронографа), язык которых был архаичен и чужд им, из-за чего в летописи встречаются крайне тяжеловесные обороты.

Имеются и такие случаи, когда ошибки сопровождают корректные высказывания и поправки. ${ }^{38}$

Хл без даты, И под 1231 г. Так интерпретировали: Самоквасов Д. Я. Заметки по истории. С. 54-55; Аинниченко И. А. Вече в Киевской области. С. 5; Крип'якевич I. П. Галицько-Водинське князівство. К., 1984. С. 122; Свердлов М. Б. Генезис и структура. С. 53; Granberg Jonas, Veche in the Chroniclers of Medieval Rus', 86. С другой стороны, некоторые исследователи считают, что не названы “дюди”, и в данном случае состоялось обычное вечевое собрание галичан, но "боярская партия" была ослаблена отступничеством большей части бояр. См.: Владимирский-Буданов М. Ф. Обзор истории. С. 64, 68; Грушевський М. С. Історія України-Руси. Т. 2. С. 476.; Софроненко К. А. Общественно-политический строй Галицко-Волынской Руси XI-XIII вв. М., 1955. С. 112; Котляр Н. Ф. Формирование территории и возникновение городов Галицко-Волынской Руси IX-XIII вв. К., 1985. C. 137 ».

(37) Возможный перевод таков: «сам Данил созвал совет, оставшись с 18 отроками и тысяцким, и сказал им».

(38) Один из них - критика предположения, высказанного в моей книге в прим. 13 на с. 23, о возможности ошибки писца в одном из текстов Успенского сборника (в рецензии с. 417-418). Хотя рецензент верно отмечает погрешности при расставлении знаков препинания в цитате, П. В. Аукин приводит фразу, оформленную по правилам современной пунктуации, ссылаясь на соответствующую страницу издания Успенского сборника: «...въстанеть ти братъ . не кычения дъдьма не въча азъ въставлю братъ ти . нъ нарочьно въстанеть рекыи искоушая еи въроу». Делая вывод о «прозрачности» или непрозрачности синтаксиса для древнего писца, необходимо учитывать древнюю, а не современную, пунктуацию и исходить из того, что было перед глазами книжника. Точно так же, при оценке возможности ошибок в евангельских сюжетах следует опираться не на соображения здравого смысла (ср. восклицание П. В. Аукина «Или древнерусский книжник не знал этого хрестоматийного евангельского рассказа?», - о Лазаре), а привлекать специальные работы. П. В. Дукин мог бы обратиться к уже упоминавшемуся труду Брюса Мецгера, где, в том числе, приводятся ошибки, возникавшие при переписывании Нового Завета. Некоторые из них совершенно замеча- 
Пример на с. 420 способен приоткрыть «рецензионную кухню» П. В. Лукина, и на нем следует остановиться подробнее. Рецензент, по его словам, «илдюстрирует непонимание Т. А. Вилкул древнерусских текстов»: пишет о том, что ошибки прочтения в монографии ведут к неверной интерпретации и к приписыванию слову «дружина» значения, которое текстами не подтверждается ('дружина как участники веча'). Что имеется лишь одно известие, где упоминается «дружина» и «само слово «вече»» - 1015 г., и оно неверно проинтерпретировано, а остальные не имеют значения и «отношения к делу».39

тельны. Один из примеров: копиист, списывая родословие Иисуса с текста, написанного в 2 столбца, и пытаясь поместить его в один столбец, перепутал все имена, и в результате имя Бога попало в середину списка и он оказался сыном Арама. См.: Мецгер Брюс, Текстология Нового Завета..., 190. Между тем, в этом и иных случаях речь шиа о писцах, знавших Евангелия. Необходимо помнить о том, что при переписывании запоминалась обычно ближайшая краткая синтагма, что также способствовало появлению ошибок (масса примеров в рукописях). Вдобавок, сочетание «нарочьно» или «нарочито» +глагол, вероятно, не было для книжника стодь необычным, каким оно есть для современного русиста. Ср. в Хронике Амартола, Ам. 259 «и того ради въ тъ дёь соуботныи нарочито именоують римлане». Учитывая все вышесказанное, мое предположение о возможности ошибки, способствовавшей появдению слова

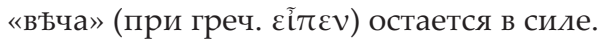

(39) Для точности, процитирую эти высказывания П. В. Аукина: «...существует напрасно якобы не отмеченное словарями древнерусского языка значение слова “дружина”-“участники веча”. Но в действитедьности составители словарей поступали совершенно верно, не отмечая этого фантастического значения. Дело в том, что все примеры, которые приводит в подтверждение своего тезиса Т. А. Вилкул, либо опять-таки основаны на элементарном непонимании текста, либо на его неправидьной (или неполной интерпретации). Прежде всего, исследовательница смогла найти тодько один пример, в котором есть само слово “вече”, известие ПВЯ под 1015 г. о конфликте Ярослава и новгородцев. В нем, по утверждению автора, “новгородцы, собравшиеся на вече, в речи князя названы также “дружиной'” (с. 72, 294). Однако в источнике - совсем другое. [далее цитата из летописи] Т. А. Вилкул явно принимает чтение большинства списков ПВА..., но в этой версии «дружина» не обозначает участников веча, а представляет собой риторическое воскдицание, сетующего о гибели «нарочитых мужей» Ярослава. Все же остальные примеры отождествления веча и дружины, приводимые автором, в принципе, не имеют отношения к делу: во-первых, вече в них вообще не упоминается, во-вторых, во всех случаях слово “дружина” можно яегко объяснить вполне традиционно» (везде подчеркнуто мною - Т. В.). 
Что касается известия 1015 г., имеется в виду следующий текст: ${ }^{40}$ «заоутра ${ }^{41}$ же собравъ избытокъ ${ }^{42}$ новгородець ${ }^{43}$ Ярославъ ре ${ }^{4}$. о люба моя ${ }^{44}$ дружина юже вчера избихъ ${ }^{45}$ а нынъ быша надобъ . и оутре слезъ . и ре $^{4}$ имъ ${ }^{45}$ на въчи».

Здесь упоминается «избытокъ» ('остаток') новгородцев. К «избытку» («имъ») обращается Ярослав в своей речи. Этот «избытокъ» вместе с теми людьми, которые иссекли варягов ${ }^{46}$ и были, в свою очередь, посечены Ярославом, представляет собой, по-видимому, политическую общность «всех новгородцев». В основе интерпретации лежит следующий перевод: «о любимая моя дружина - та, которую я вчера посек», что предполагает наличие «всей дружины», аналогичное политической общности «новгородцев». Т.е. высказывание П. В. Аукина о том, что в источнике «совсем иное», отнюдь не бесспорно.

Прямое упоминание, где слово «вЂче» исподьзуется наряду со словом «дружина», действительно единственное. Однако в моей книге прямо указано, что прямых упоминаний в древнерусских летописях - абсолютное меньшинство (с. 27-31), и опираться исключительно на прямые сообщения о вече было бы абсурдным. В частности, имеются параллельные известия двух или трех летописных сводов, когда лишь в одном из них собрание названо вечем, а в других оно так не называется. Бо́дьшая часть рассказов о новгородских собраниях также не содержит слова «вече», отсутствует оно и в знаменитом

(40) Сообщение 1015 г. известно в пяти списках ПВ А, а также в составе Сильвестровско-Минейной редакции «Сказания о Борисе и Гдебе», см.: Т. А. Вилкул, Летописные вставки из ПВЛ в Сильвестровско-Минейной редакции «Сказания о св. Борисе и Глебе», Ruthenica 5 (2006) 37-72, Интернет-версия статьи: http://history.org.ua/0/?1=spdf\&pdfn=5\&pdfy=200

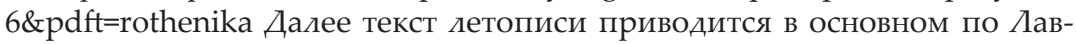
рентьевскому списку, варианты подведены из др. списков.

(41) Р Наоутра, Ак Наоутрии

(42) Сильв-Минейн прокь

(43) так АХ, Сильв-Минейн новгодецъь; РАИ новгородияевь

(44) так $\Lambda$, Сильв-Минейн люба моя, Х о любаа моа; РАИ о любимая

(45) в $А$ проп. а ныню... ими.

(46) Они названы также «нарочитыми мужами», но наличие разных обозначений обычно для древнерусских текстов. В рецензируемой книге приводится пример, когда одна и та же группа из 3-х человек, перечисленных поименно, названа «мужами», «боярами» и «дружиной» (с. 107). 
рассказе о восстании 1136 г. ${ }^{47}$ В рецензируемой П. В. Лукиным монографии обосновывается тезис, что необходимо учитывать косвенные сообщения. Этот тезис рецензент не опровергает и даже не обсуждает, но полагаю, что обратное доказать не удастся. Соответственно, известие 1015 г. не играет основной роди в исследовании. При решении вопроса о «дружине» в книге были привлечены, в частности, сообщения Ипат. и Лавр. 1175-1177 гг., где упоминание веча косвенное, cм. на с. 72:

«...увъдевше же смерть княжю (Андрея Боголюбского - Т. В.) ростовци и сужьдалци и переяславци и вся дружина от мала до велика, съЂхашася к Володимерю и рбша.... по кого хочемъ послати в своихъ князех... И прибхавше сли (послы к избранным людьми князьям, Мстиславу и Ярополку Ростиславичам - Т. В.), повъдаша речь дружиньню». Далее приводятся благодарственные речи Ростиславичей: «Помози Богъ дружинъ, оже не забывають любве отца нашего». ${ }^{270}$ Описывается процеду-

(47) В книге на с. 31 приведена статистика:

«В НП 1 на 70 упоминаний о собраниях новгородцев в XII в. записей со словом "въче" - $0^{49}$, в Лавр на 15 косвенных сообщений о вече приходится 1 прямое ${ }^{50}$, в Ипат. соотношение, соответственно, 17/6 ${ }^{51}$ ».

Прим. 49: «Одно - в том случае, если учитывать известие 1193 г. в НП мл. ред., имеющее характер вставки. Косвенные известия - см. в НП статьи 1125 г., 1126 г., 1128 г., 1130 г., 1132 г., 1134 г. (упоминается 2 раза), 1135 г., 1136 г. (2), 1137 г. (2), 1138 г. (2), 1139 г. (2), 1141 г. (2), 1142 г. (2), 1144 г., 1146 г., 1148 г. (2), 1154 г., 1156 г. (2), 1157 г., 1160 г. (2), 1161 г., 1166 г., 1167 г. (2), 1168 г., 1169 г., 1170 г., 1171 г., 1172 г., 1175 г. (2), 1176 г., 1177 г., 1178 г. (2), 1179 г., 1180 г. (3), 1181 г., 1184 г., 1186 г. (2), 1187 г., 1188 г., 1189 г., 1191 г., 1193 г., 1194 г., 1195 г. (3), 1196 г. (2), 1197 г. (2). НI, с. 21-45. На этот феномен не так часто обращают внимание. Обычно считают, что в НП слово «въче» встречается чаще, чем в других сводах, что верно тодько для XIII в. См.: Львов А. С. Лексика «Повести временных лет». С. 192. На отсутствие прямых упоминаний до конца XII в. обратила внимание Подвигина Н. А. Очерки социально-экономической и подитической истории. С. 104».

Прим. 50: «См. статьи Лавр: 1102 г. 275-276Д (входит в ПВ 1); 1138 г. (2),

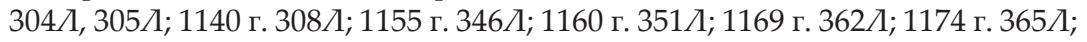
1178 г. 386 $; 1182$ г. 388Д; 1186 г. 400Д; 1188 г. 406Д; 1197 г. 414Д; 1200 г. 415-416Д. Прямое - под 1176 г., 377 \».

Прим. 51: «Косвенные известия о новгородских собраниях в Ипат.: 1102 г., $251 И$ (из ПВА); 1154 г., 468И; 1158 г. (2), 491И; 1161 г. 518И, 1168 г., 529И; 1170 г., 543И; 1173 г., 566И; 1178 г. (2), 606-607И, 609-610И; 1180 г., 624И; 1196 г., 702И. Прямые известия: 6648/1141 г., 307И; 1148 г., 370И; 6668/1160 г., 510И; 6669/1160 г. (2), 510И; 6677/1167 г., 537И». 
ра крестоцелования новым князьям, и «дружина» стоит на том месте, где обычно видим горожан. ${ }^{271}$

270 371-372 - 595И. Ср. также обвинение летописца, предъявленное той самой дружине, в том, что они забыли крестоцелование к князю Юрию (Долгорукому) и посадили на столе Андрея Боголюбского. Оно отсылает к статье 1159 г., где речь идет о «суздальцах и ростовцах»; $372 \lambda$ - 595И. Кроме того, см. статью 1176 г.: «...дружинъ не сущи вь градъ, ьхали бо бяхут противу Ярополку», этот фрагмент Ипат. дополняет общее с Лавр чтение: «...не сущимъ володемерцемъ Володимери... Бхали бо бяху... противу князема»; 373 - 596-597И.

${ }^{271}$ В 1176 г. «Ярополкъ же пођха отаи брата к дружинъ Переяславлю... а дружина вся ... утвердившеся крестным цълованьемь с ним»; 373 А - 596И. «...тя привели старђишая дружина, ... тобе ростовци привели и боляре, а мене былъ с братомъ Богъ привелъ и володимерци»; 380 1.

Эти известия имеют некоторое «отношение к делу», поскольку собрания ростовцев и суздальцев, небезосновательно квалифицируемые исследователями как упоминания о вече, в них названы также «дружиной», и «объяснить традиционно» эти тексты едва ди возможно.

Как видим, на деле «илдюстрация непонимания Т. А. Вилкул древнерусских текстов» оборачивается иллюстрацией методов рецензирования П. В. Лукина. Имеем дело с попыткой выдать неоднозначную интерпретацию за однозначную, замалчиванием основных положений, обсуждаемых в книге, и важных текстологических свидетельств.

\section{По поводу «деконструкции иностранных языков».}

П. В. Аукин продемонстрировал свою эрудицию и проделал огромную работу (вплоть до того, что отметил, что однажды Клаус Цернак неверно назван Цорнаком на с. 14, см. с. 422 рецензии). Однако когда рецензент выходит за рамки корректорских поправок и речь заходит о содержательной стороне, его высказывания во многих случаях не соотносятся с действительным положением вещей.

Так, П. В. Аукин предъявляет упрек в том, что автор приписывает Клаусу Цернаку «мнения, которых он не придерживался». Немецкий ученый считал чтение Воскресенской летописи более логичным, и писать о том, что он принимад чтение Киевского свода (отличающееся от Воскресенской), якобы значит «принципиально искажать его позицию» (с. 422). Глубокоуважаемый коллега, к сожалению, недопонял, о чем идет речь. В книге обсуждается обязательность или необя- 
зательность принятия конъектуры при согласном чтении обоих списков Киевского свода, Ипатьевского и Хлебниковского. В прим. 273 на с. 73 читается следующее:

«Спорят, как читать: «дружину кияне» (так ИХА) или «дружину и кияне» (конъектура). А. Е. Пресняков считал, что конъектура здесь издишняя, это мнение принял Клаус Цернак».

Если обратимся к книге Клауса Цернака, то в его переводе соответствующего фрагмента Ипат., прочтем следующее: «...seine Bojaren und seine gesamte družina, die Kiever, und sagte zu ihnen» (курсив мой. T. В.; после die Kiever - ссылка: Die Voskresenskaja-Chronik verbindet "družina" und "Kiever" sinngemässer durch "und", PSRL VII, S. 65) ${ }^{48}$. Немецкий ученый в свой перевод конъектуру не вводит. С учетом того, что в исследованиях, предшествующих книге А. Е. Преснякова, конъектура считалась необходимой, такой шаг свидетельствует о принятии варианта Ипат. и о признании того, что конъектура не обязательна.

Издишне категоричен рецензент и в иных случаях. Напр., он пишет по поводу списка начадьных форм греч. соответствий слову «въче» на с. 23:

с. 422-423, «ошибки здесь буквально в каждом слове. Так,

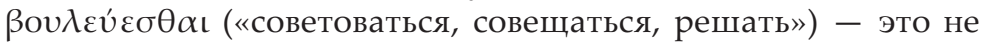

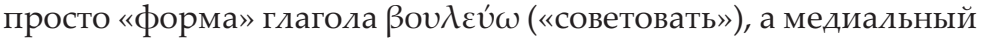
залог с другим значением... Разумеется, лексема «въче» никак

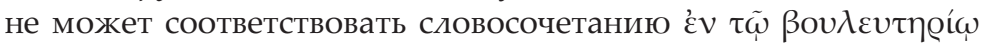
на самом деле, ему соответствует словосочетание «въ въчи»...

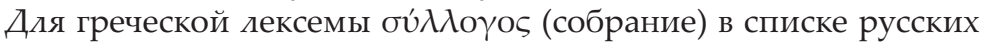
соответствий аналога нет, как и для русского «собираться» отсутствует греческий аналог».

В словарях обычно приводится одна исходная форма и, как пра-

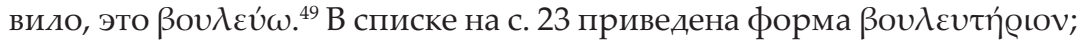

(48) K. Zernack, Die burgstädtischen Volksversammlungen bei den Ost- und Westslaven (Wiesbaden, 1967) 68. Текст летописи: «Изяславъ же /Хлебн доб.: съзва/ бояры своя . и всю дроужину свою кияне и рече имъ», ПСР $А$, т. 2, стб. 343-344.

(49) См., напр., Liddell-Scotт, p. 325; T. Muraoka, A Greek-English Lexicon of the Septuagint (Twelve Prophets) (Louvain: Peeters, 1993) 38 (раздичие значений залогов не оговаривается, примеры в т.ч. в мед.-пасс.); Симфония на канонические книги Священного Писания с еврейским и греческим ука-

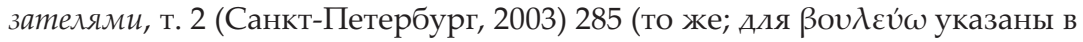
т.ч. значения «посоветуется, решились, умышляли»); A Homeric Diction- 
«лексема «въче» соотносится с нею. Если П. В. Дукин хочет сказать,

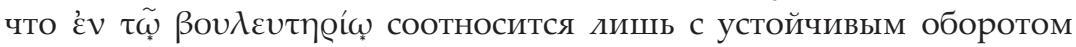
«въ въчи», то необходимо обосновывать надичие такого устойчивого оборота в X-XI вв. (время перевода Хроники Амартола, откуда взято выражение; следует учитывать то, что славянские переводчики часто руководствовались пословным, а в некоторых случаях, поморфемным принципом перевода). ${ }^{50}$ Что касается «отсутствия аналога» (послед-

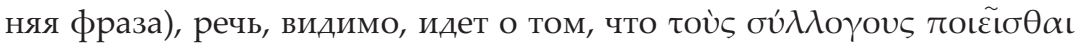
передано как «собираться». Однако в теории перевода такие явления называются не «отсутствием аналога», а «неточным соответствием»; ;1

ary, based upon the German of Georg Autenrieth, transl. by R. P. Keep (Norman: University of Oklahoma Press, 1958) 62 (раздичие оговаривается, но 'deter-

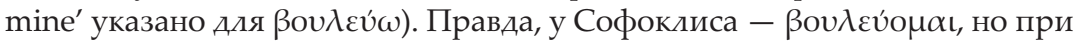

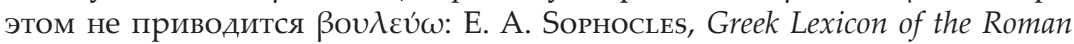
and Byzantine Periods (Zürich-New York, 1992) 314.

(50) Возможно, рецензент принял мнение Йонаса Гранберга, показавшего, что в поздних текстах словосочетание «в въчи» стало устойчивой формулой (J. Granberg, Veche in the Chroniclers of Medieval Rus': A Study of Functions and Terminology (Göteborg, 2004)), но у Гранберга речь идет именно о поздних свидетельствах новгородских и псковских летописей. Если считать, что это положение справедливо и для перевода Амартола, сочинения переводного, а не оригинального, и датируемого не XIV-XV вв., a X или XI в., то тогда необходимо привести доказательства, привлекая ранние переводные тексты. Каковые, кстати, крайне немногочисленны, хотя новые находки и возможны. Напр., недавно мне удадось дополнить список таких чтений: в Иудейском хронографе, по Виленскому спис-

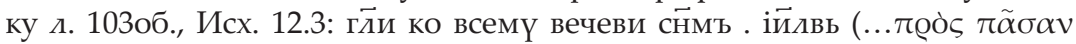

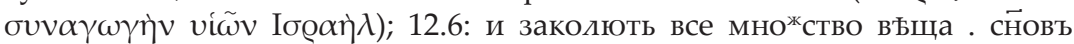

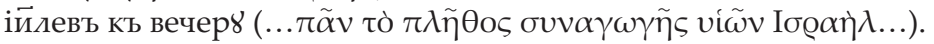

(51) Неточные соответствия обычны в переводах, в т.ч., кстати, обычны при переводе с греческого древнеславянскими книжниками. См., напр., Хроника Иоанна Малаль, кн. 2, гл. 14: «сьстарбвся и больвь оумръ»

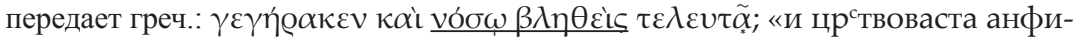
$\mathrm{O}^{\mathrm{H}}$, и

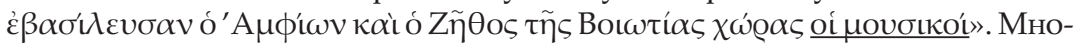
го внимания подобным примерам уделял В. М. Истрин, см. Хроника Иоанна Малалы в славянском переводе (Москва, 1994) (комментарии к каждой

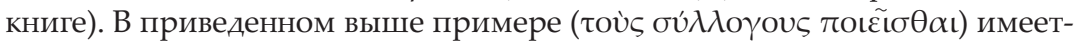
ся еще такая сложность: в современном русском нельзя сказать «собраниям делаться /совершаться», как невозможны и многие иные конструкции, допустимые в древнеславянском. Вдобавок, «созывать» иди «устраивать собрания» устойчиво ассоциируется с комсомольско-партийно-профсоюзной деятельностью, т.е. привносит иной смысловой оттенок. 
взаимное же нулевое соответствие ${ }^{52}$ невозможно. Создается впечатление, что рецензент изобретает собственные правила, не согласовав их с тем, как принято поступать в подобных случаях, отчаивается, что автор книги им не следует, и пишет об «ошибках в каждом слове».

Напоследок, небольшая ремарка по поводу фрагмента хроники Сигеберта из Жамблу. В книге действительно привлекался перевод М. Б. Свердлова, опубликованный в книге: Латиноязычные источники по истории древней Руси (М., 1989). Но, думаю, следует учитывать то, что никто не застрахован от ошибок, даже переводчики высокого класса. Зная о разногласиях питерских и московских коллег, я не считаю нужным вмешиваться (рецензент же вмешался «подпольно» и достаточно своеобразным образом, ${ }^{53}$ см. в его рецензии с. 424). Тем более, что для целей моей книги было важно то, что в этой хронике сообщалось об изгнании Изяслава Ярославича «всей землей», в то время как из ПВЯ известно об изгнании Изяслава его братьями-князьями, и именно это расхождение было предметом рассмотрения.

\section{К «деконструкции исторического анадиза» П. В. Дукина.}

Этот пространный раздел вкдючает множество претензий, которые, в отличие от предыдущих, могли бы повдиять на оценку результатов исследования. При одном условии - если бы замечания рецензента были бы справедливыми. Однако ближайшее рассмотрение показывает, что утверждения П. В. Аукина не соответствуют действительности. Ниже привожу наиболее примечательные образцы его суждений. Почти каждый из помещенных ниже примеров требует детального анализа и точного цитирования слов рецензента, поэтому читателю потребуется некоторое терпение.

1) Интересный пассаж встречаем на с. 425; кстати, его П. В. Аукину выгоднее было бы поместить в «деконструкцию текстологии». Это один из немногих случаев, когда рецензент затрагивает тезис о противоречиях в параллельных версиях летописей (см. 2-ю главу, св. 100 страниц текста), но старается создать впечатление, что никаких противоречий нет. При этом, обнаруживает непонимание содержания рецензируемой им книги.

(52) Как правило, «отсутствие аналога» называется «нулевым соответствием».

(53) Ссылаясь не на перевод А. В. Назаренко, см. А. В. НАзАренко, Древняя Русь на международных путях. Междисцииплинарные очерки культурных, торговых, политических связей IX-ХІІ веков (Москва, 2001) 530, - а попытавшись создать видимость собственной деятельности. 
«Все случаи поиска мнимых противоречий в летописных известиях, позволяющих автору пространно распространяться о "нарративном конструировании", невозможно перечислить. Здесь можно легко выбирать любой эпизод наугад. Вот Т. А. Вилкул пишет о борьбе за Киев после смерти Изяслава Мстиславича, и, естественно, сразу же в рассказах о ней целую россыпь “неувязок" (с. 149). Летописи, например, сообщают о приглашении киевлянами на княжение Изяслава Давыдовича из-за страха перед половцами. Автор удивляется: ведь “половцы находились как раз в войске Изяслава и угроза исходила именно от него". Что здесь удивительного, непонятно. Киевляне, естественно, боялись погрома своего города степняками-союзниками Изяслава - и, стремясь его избежать, вынуждены были признать его князем».

Прежде всего, относительно неувязок: в книге речь идет не об Изяславе Давыдовиче и половцах, а о редактировании текста Ипат., при котором возникди несогласования с предыдущим слоем летописных записей. При определении сравниваются соответствующие фрагменты Ипат. и Лавр. ${ }^{54}$ Т.е., судя по всему, рецензент не понимает

(54) Текст книги, с. 149: «Ипат включает дополнительные блоки сведений о Ростиславе Мстиславиче ${ }^{140}$, вписанные симпатизировавшим ему летописцем, и множество деталей, касающихся других князей. Часть из них привела к неувязкам с фрагментами общего с Аавр текста, что свидетельствует об очевидно позднем редактировании Киевского свода. Например, племянник Ростислава Мстислав Изяславич бросает дядю, войско еще два дня бьется с половцами, и половцы даже "смятошась" ('пришли в замешательство', слово, употребляемое обычно в победных описаниях бегства врагов). После чего руские князья в спешке бегут, причем Мстислав бежит вместе с остальными, чего не могло быть, если бы сражение в самом деле продолжалось еще два дня после его ухода. В Лавр этого двухдневного периода нет. Далее, в дополнительных фрагментах Ипат сын Ростислава Святослав спасает отца, а в общем с Лавр тексте он бежит вместе со Мстиславом, то есть отдельно от Ростислава. Оба фрагмента Ипат следуют один за другим, и, таким образом, Святослав “пребывает” одновременно в двух разных местах ${ }^{141}$ ».

Прим. 140: «Радость киевлян по поводу того, что Ростислав пришел в Киев (470-471И); справедливое наделение им Святослава Всеволодича (471И); оказание помощи Мстиславу Изяславичу (471-472И); щедрая раздача “имъния" Вячеслава церквям, монастырям и убогим (473И); описание битвы с половцами, где Ростислав бьется с врагами, а не бежит при одном их виде (475И). См. также вероятный пропуск фрагмента общего с Лавр текста. По Лавр, Юрий “Не помяня здобы брата его 뜬 его”, то есть Изяслава Мстиславича и самого Ростислава. В Ипат тодько “здобы брата его”, значит, одного Изяслава; 476И - 344Л. 
того, что обсуждаются текстологические приметы (!). Относительно приглашения черниговского князя Изяслава. В моей книге пишется о том, что летописец пытается уверить читателя, что киевляне не предавали своего князя, и, одновременно, старается воспрепятствовать напрашивающемуся предположению, что поступок горожан уж очень похож на капитуляцию после поражения в войне. Отмечается и тот факт, что исследователи уже обращали внимание на странную «добровольность» приглашения Изяслава, сделана ссылка на книгу Н. Ф. Котляра. ${ }^{55}$

В целом, на с. 148 предварительно сравнивается сообщение Ипат. и сообщение НП $\lambda$; об НП $Д$ подробнее речь идет далее, на с. 151. «Выбирая наугад» это параллельное известие, рецензенту следовало бы уведомить читателей о том, что я анализирую три текста: Ипат., Давр. и НПЛ. В том числе, привожу свидетельство НП Д, где об Изяславе Давыдовиче сказано, что он сел в Киеве без приглашения киевлян, тогда как в Ипат. и Лавр. (представдяющих собой две редакции одного рассказа, почему и необходимо было оговорить особенности редакторской работы летописца) подробно описывается приглашение. Всего в 1-м разделе 2-й главы привлекаются 10 параллельных сюжетов; ${ }^{56}$ для получения более четкой картины в завершении раздела приводится таблица наличия формантов этой нарративной модели (с. 160). Среди параллельных известий - такие, напр., как ослепле-

Прим. 141: «Подробнее: Вилкул Т. А. О происхождении общего текста, 53-56».

(55) Текст, с. 148-149: «Детописец, похоже, хотел сказать, что Ростислав сам был повинен в своем несчастье, оказался плохим политиком, и, во всяком случае, его никто не предавал (что вызывает сомнения в свете данных НП 1 , см. ниже). После поражения киевляне вынуждены были пригласить на стол черниговского князя, и вновь нет речи о предатедьстве - говорится о мирном приглашении на свободный стол из-за страха перед половцами, хотя половцы находились как раз в войске Изяслава и угроза исходила именно от него ${ }^{138}$.

“Тогды же тяжько бысть кыяномъ, не остал бо ся бяшеть у них никаковъ князь. И послаша кыяне... по Изяслава по Давыдовича, рекуще: поиди г Кыеву, ать не возмуть нас половци"».

Прим. 138: «Отмечалось, например, в: Котляр Н. Ф. Древнерусская государственность. С. 339».

(56) Кстати, параллельное сообщение 1154 г. достаточно сложно для анализа, поскольку Ипат. и Давр. имеют общие фрагменты текста, версия Ипат. сильно редактирована, а НП $л$ лапидарна. Поэтому оно помещено в конце ряда параллельных известий нарративной модели «Оправдание / осуждение князя». 
ние Ростиславичей их дядей Всеволодом Юрьевичем или история повешения Игоревичей в Галиче. Два ослепления или два повешения одних и тех же князей вообразить себе невозможно, ${ }^{57}$ тем временем, в одной из летописей это деяние приписывается князю, а в другой (других) - «людям».

Таким образом, противоречия в параллельных текстах действительно существуют, но П. В. Аукин «борется» с этим непреложным фактом своеобразным способом: замалчивая то, что в монографии проведен анализ серии параллельных известий, и позволяя себе сразу два неадекватных тексту рецензируемого им исследования высказывания в одном абзаце. А именно, относя неувязки не к редактированию в Ипат., а к известию о приглашении Изяслава Давыдовича, и «забывая» сообщить о том, что «псевдодобровольность» поступка киевлян уже отмечалась исследователями. Впрочем, скорее всего, сознательное искажение одно, а высказывание о «россыпи неувязок» связано с непониманием содержания. Иначе говоря, весьма велика вероятность того, что оппонент не понял, что «неувязки» отмечаются в редактированном тексте Ипат. и что приводятся доказатедьства редактирования: наличие швов и противоречий. В таком случае его квалификация в области текстологии оказывается под сомнением, но выбор именно таков: искажение либо непонимание.

2) Следующий пример, по замыслу рецензента, должен продемонстрировать неверность другого тезиса автора, о неустойчивости летописной терминологии. Текст Повести временных лет вызывает у П. В. Аукина «простую мысль»:

«В рассказе о белгородском киселе (ПВД под 997 г.) старейшины градские и «люди», разумеется, не отождествляются, а составдяют разные группы населения, что прямо вытекает из слов самих старейшин: “Не стерпять людье глада”. Комментарии автора только запутывают вполне ясный текст. Сообщение о том, что старцу, которые не был на вече, “людье поведаша... яко утро хотять ся людье предати печенъгом", Т. А. Вилкул снабжает такой ремаркой: "людье (собеседники старца. - Т. В.) поведаша... яко утро хотят ся людье (на этот раз участники веча) предати печенегом". Простая мысль о том, что собеседники старца наверняка тоже были участниками веча, очевидно, не приходит украинской исследовательнице в голову» (с. 425).

(57) Эти два сюжета в книге - с. 117-124, 129-130; см. также в более доступной для российского читателя статье: Т. А. Вилкул, Конструирование нарратива в параллельных летописных сообщениях о вече, в: Древнейшие государства Восточной Европь (Москва, 2004) 212-222. 


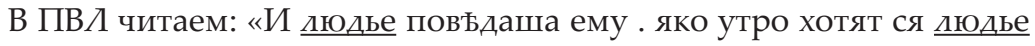
предатися печенъгом . се слышавъ посла по старьишины градьскыя . и рече имь слышахъ, яко хочете ся передати печенбгом . они же рбша . не стерпять цюдье глада». Напомню, в книге речь идет о том, что одна и та же группа людей летописцем могла обозначаться по-разному и, наоборот, одно и то же название могло исподьзоваться для обозначения разных групп; пример с «белгородским киселем» приводится как иллюстрация этого положения. При переводе на современный

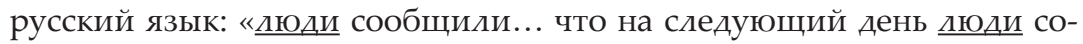
бираются сдаться...» (члены одной группы говорят о другой в третьем лице). Если попытаться создать аналогичную конструкцию: «москвичи сообщили ему... что... москвичи... собираются... и воззвал он к руководящим дицам, и сказал им: “Слышал, что собираетесь...”, они же ответили: “Не вытерпят москвичи..."” («москвичи» можно заменить на «киевляне» и пр.). Часто ли говорят о себе в третьем дице, а потом заменяют это иным обозначением $?^{58}$ В моей книге речь идет не о том, что собеседники старца могли быть или могли не быть участниками веча, но о том, что в данном фрагменте слово «дюдье» имеет разные значения: 'случайная (и, видимо, небольшая) группа собеседников' белгородского старца и 'политическая общность', принимающая решение о сдаче города; последняя названа также «старђишинами градскими». «Простая мысль» рецензента показывает то, что он не понимает в данном случае текста летописи - здесь достаточно простого.

3) Далее рецензент обращается к свидетельству Жития Авраамия Смоленского, и высказывает аналогичные претензии - непонимание текста автором и неверность тезиса о неустойчивости терминологии - пополняя их упреком в «выборочном цитировании»:

«Не меньшую родь играет и такой старый (но недобрый) метод, как “выборочное” (в свою пользу) цитирование, меняющее порой смысл текста на противоположный... Фраза цитируется следующим образом: “Събраша же ся вси от мала и до велика, весь градъ на нь (Авраамия. - Т. В.)... Всем же собравшимся на дворъ владыченъ, игуменомъ же и попомъ, и черньцемъ, княземъ и боляромъ, диакони и вси церьковници..." (и далее говорится о суде). А вот что скрывается за первым многоточием: “...градъ на нь, инии глаголють заточити, а инии къ стьнъ тоу пригвоздити и зажещи, а дроузии потопити и, проведше

(58) Если только речь не идет об ироническом контексте, что для древнерусских летописей невозможно. 
въсквозъ градъ. Всем же собравшимся". Нетрудно заметить, что “весь град" лишь требовал расправы с Авраамием, а к судившим его это словосочетание не применяется» (с. 427).

Прежде всего необходимо отметить, что ратующий за полноту цитирования рецензент «забывает» продолжить цитату, приведенную в книге на с. 66: «Посланыя же слугы, емше, яко злодъа влачяху... и весь градъ, и по торгу, и по улицамъ - везде полна народа, и мужи же, глаголю, и жены, и дъти». Речь идет о том, что словосочетание «весь градъ» в двух соседних фразах жития использовано в разных значениях: для обозначения собравшихся на судилище на «дворь владычень» и для обозначения наблюдавших позор Авраамия жителей Смоленска. И это действительно так. ${ }^{59}$ Если остановиться на свидетельствах Жития подробнее, следует отметить следующее. «Дъти» вряд ли могди желать «заточити и пригвоздити», тем более, что буквально несколькими строками выше «попы» жаловались на то, что святой «уже наши дъти вся обратиль есть». ${ }^{60}$ В Житии выражение «весь градъ» встречается также ранее, в повествовании о наличии в «граде» сочувствующих Авраамию и о сопротивлении ему в «официальных кругах»: «...и пакы не преставааху, крамолы на нь въздвизающе въ градъ и везде, глаголюще: «Се уже весь градъ к собъ обратиль есть». ${ }^{61}$ Эти учтенные при написании монографии известия не цитировались, поскольку в книге с достаточно широкой тематикой невозможно поместить все свидетельства источников. Не говоря уже о том, что никак нельзя было предусмотреть, что пытливый рецензент, предъявляя претензии, не ознакомится с несколько более широким контекстом, нежели фрагмент, охватывающий менее одного ииста текста жития. Наконец, возвращаясь к исходной фразе, столь категорически истолкованной П. В. Аукиным: из Жития Авраамия не следует, что к судившим святого словосочетание «весь градъ» не применяется - «все»

(59) Без купюр этот фрагмент Жития выглядит следующим образом: «Събраша же ся вси от мала и до велика весь градъ на нь: инии глаголють заточити и, а инии къ стънъ ту пригвоздити и зажещи, а друзии потопити и, проведше въсквозе градъ. Всъм же собравшимся на дворъ владычень, игуменомъ же и попомъ, и черньцемъ, княземъ и боляромъ, диакони и вси церьковници, внегда послаша по блаженаго, уже всъмъ собравшимся. Посланыя же слугы, емше, яко здодъа влачяху, овии ругахуся ему, инии же насмихаахуся ему и бесчиная словеса кыдающе, и весь градъ и по торгу, и по улицамъ - вездъ подна народа, и мужи же, глаголю, и жены, и дъти, и бъ позоръ тяжекъ видъти».

(60) ПДДР. ХІІІ век (Москва, 1981) 80.

(61) Там же, с. 74. 
предварительно обсуждали и «все» собрались. Таким образом, мое прочтение опирается на полный текст Жития Авраамия Смоленского, рецензент же, очевидно, исходия из чего-то иного.

4) Далее, разбирая известия о степняках и дружине в Киевском своде (ПСР Я, т. 2, стб. 424-428), рецензент обвиняет меня в «глухих ссылках» (в книге с. 81, ссылки занимают часть текста примечания 321), неточном воспроизведении иетописи, неверной расстановке современных знаков препинания, замене «рекуче» на «рекоша» при цитировании Ипатьевского свода и, в целом, неправильной интерпретации. Степняки-де не могли входить «іn corpore» в состав дружины, следует писать о том, что «характеризуется состав войска»: сначала дружина, затем остальные составляющие (киевляне, черные клобуки и т.п.). Сразу необходимо отметить, что в цитатах П. В. Аукин применяет весьма примечательные сокращения и использует не древнюю пунктуацию, а современную. ${ }^{62}$

(62) См. с. 427-429: «Еще один “деконструктивный” способ, применяемый Т. А. Вилкул, очень прост (так и хочется сказать, до неприличия). Назовем его методом гдухих ссылок. Автор, скажем, утверждает, что в “Киевском своде" в составе Ип. “есть перечисления, где дружина отделена от степняков, и такие, где степняки... вкдючаются в состав дружины” (с. 81)... В подтверждение данного тезиса Т. А. Вилкул приводит три упоминания "под 1151 г., где дружина - общее название для киян и черных кдобуков" (с. 81, сноска), на стб. 424, 426, 428 шахматовского издания Ип. Первое и третье упоминания даются в глухих ссылках, второе приводится в весьма своеобразном виде (об этом ниже). Обратимся к летописному тексту. Стб. 424: “Вячьславъ же, и Изяславъ сь братомъ своим Ростиславомъ, и съ Изяславомъ Давыдовичемъ, и съ Ярославомъ братом своимъ, и с Городеньским княземъ, и с дроужиною своею, и с Кияны, и с Черными клобукы... поидоша...". Характеризуется состав войска: сначала перечисляются князья, потом упоминается дружина, потом киевляне, потом черные клобуки. Ни малейших оснований считать последних частью дружины нет. /то же о тексте, стб. 428; далее рецензент пишет о неверном воспроизведении мною текста/ Вот что на самом деле написано в источнике: “Дроужина же Вячеславля, и Изяславля, и Ростиславля, и всих князии оустягывахоуть от того /военных действий. - П. А./, и Кияне, наипаче же Чернии Клобоуци от того оустягоша, рекоуче... Вячеславъ же, Изяславъ и Ростиславъ послоушавше дроужины своея, и Киянъ, и Черныхъ Клобоуковъ...". Во-первых, как и в двух других упоминаниях, дружина здесь часть войска, черные клобуки в нее, разумеется, не входят (более того, здесь как будто специально уточняется, что черные клобуки не хотеди воевать больше, чем другие (“наипаче”): дружинники и киевляне). Во-вторых, выясняется, как “работает” с источниками Т. А. Вилкул: летописную фразу она отредактировала (заменила "рекоуче" на "рекоша", так чтобы 
Одно замечание среди перечисленных является верным - о «рекуче» и «рекоша». Эта ошибка вызвана исподьзованием гарвардского факсимильного издания Хлебниковского списка, где «рекоша». ${ }^{63}$ В остальном же, обратившись к тексту летописи, где современных знаков препинания нет, обнаружим, что действительное положение вещей не соотносится с картиной, нарисованной П. В. Лукиным. Прежде всего, во всех случаях в летописи описывается не «состав войска», а совещания. Говорится: «и тако оугадавше», «не оудоумаша», «почаша доумати». Рецензент всякий раз цитирует летопись без этих слов, обрывая цитаты или обозначая невыгодные для его интерпретации выражения отточием, но они, тем не менее, в летописи присутствуют. ${ }^{64}$ Я расставдяю современные знаки препинания следующим образом: «съ дроужиною своею: и с кияны, и с черными клобукы» (Ипат., стб. $424)$; «дроужина же оустягывахоуть... (и кияне, наипаче же чернии клобоуци)» (стб. 426); “дроужины своея: и киянъ, и черных клобо-

получилось полноценное сказуемое), а “ненужную” информацию (упоминание в первой части киевлян и черных клобуков) просто выкинула».

(63) Хлебниковский список представдяет, наряду с самим Ипатьевским, Ипатьевский свод. О. Рвітsaк (ed.), The Old Rus' Kievan and GalicianVolhynian Chronicles: The Ostroz'kyj (Chlebnikov) and Četvertyns'kyj (Pogodin) Codices (Cambridge, Mass., 1990) (Harvard Library of Early Ukrainian Literature, VIII) 190 (Хлебн. арк. 386). Одно время я работала с этим изданием, а не с ПСР 1 , т. 2, и, стандартизируя ссылки по Ипатьевской версии, ненароком оставила чтение Хлебн.

(64) В частности, в 1-й цитате рецензент «забыл» всего три слова, «и тако оугадавше», проставив вместо них отточие. См. ПСР 1, т. 2, стб. 424 : «и съ дроужиною своею . и с кияны и с черными клобукы и тако оугадавше поидоша». Далее (стб. 428), судя по всему, также речь идет о некоем совещании: троица князей «повелъша Володимироу поити... и тако нарядъ створше . в собъ кН̈зи и дроужина . и чернии кдобоуци . и кияне . и тако не оудоумаша». Здесь П. В. Аукин оборвал цитату. В третьем случае речь также идет о совете (стб. 426): «Вячьславъ же и Изяславъ и Ростиславъ . съзвавше бра тиву имъ бится . дроужина же... оустягывахоуть от того...». П. В. Аукин снова «укоротил» цитату. Между прочим, черные клобуки (стб. 426) говорят князю: «...а тобъ боудет оставяче своп ппшьцъю пођхати», - т. е., по крайней мере, «пешци», находившиеся в войске, в состав совещавшихся не входят. Кстати, по неизвестной причине рецензент считает, что свидетельством того, что черные клобуки не могли входить дружину, доджны быть их советы князю, обнаруживающие «нежелание воевать». Но подобные советы «дружины» не бросаться безрассудно в бой в летописях обычны, начиная с советов князю Игорю, сыну Рюрика (о последнем сюжете см. с. 77, прим. 297). 
уковъ» (стб. 427); ${ }^{65}$ «кёзи и дроужина (и чернии клобоуци, и кияне)» (стб. 428). Основание для этого следующее. Речь идет о совещаниях, а в Киевском своде находим множество иных эпизодов, где говорится о совещании князей с «дружиной», но состав при этом подробно не расписывается. Сопоставление известий позволяет сделать вывод, что «дружина» - общее, включающее понятие.

Что касается того, что «свои поганые» (берендеи, торки и пр.) не могли входить в состав дружины. Сравним два текста. Первый - речь «берендичей» Мстиславу Изяславичу, под 1159 г.: «аже ны хощеши дюбити . яко же ны есть дюбиль оць твои . и по городу ны даси по лепшему...». Второй - речь «галицких мужей» князю Ярославу Володимирковичу, под 1153 г.: «галичьскии же мужи почаша модвити кН̈зю своему Ярославу ты еси . молодъ . а поеди прочь и нас позоруи . како ны будеть оць твои кормилъ и любилъ.... ${ }^{66}$

Таким образом, моя ошибка, вызванная использованием факсимильного издания Хлебниковского списка, на самом деле не влияет существенно на интерпретацию, поскольку истолкование текста в книге опирается не на сокращение фрагмента Киевского свода, а на комплекс многочисленных и существенных свидетельств. Тем временем, рецензент, пытаясь доказать обратное, не только упускает из виду этот комплекс известий, но всячески «укорачивает» даже разбираемые им свидетельства, дабы иметь возможность определять их как описания войска, тогда как на деле речь идет о совещаниях. Вдобавок, он игнорирует известия Киевского свода, где за середину и 2-ю половину XII в. масса сведений о «своих поганых» и «дружине», и ПВ, , содержащей множество сообщений о совещаниях князей с «дружиной».

5) На с. 426-427 П. В. Аукин пишет о вече 1255 г. В книге отмечается то обстоятельство, что новгородские войска, конники и пешие, стояли в двух разных местах на окраинах города, тогда как в центре собиралось вече, причем в НП $Л$ упоминаются «старђишие» и «меншие». Рецензент считает, что при нападении на Новгород горожанам не нужно было находиться на определенном месте, они «без особых

(65) Рецензент расставдяет современные знаки препинания иначе, никак не обосновывая свое решение. Кстати, то, что П. В. Аукин проставил их строго по своему вкусу, выгдядит показательно в свете его заявлений, что исследователь должен выставдять их «максимально невыгодно для себя» (с. 421).

(66) ПСР А, т. 2, стб. 466, 501. Под 1159 г. описывается такая ситуация: князь пытается договориться с лучшими «мужами» берендичей, помогающих его сопернику, и переманить их на свою сторону. 
затруднений» могли отправиться в центр города, и ссылается на «подобные случаи». ${ }^{67}$ На самом деле имеется в виду всего лишь один «подобный случай», из описания похода 1217 г., притом, обстоятельства разнятся кардинально. В НП Л под 1255 г. описывается нападение Александра, когда князь с войском находился на околицах Новгорода. Новгородский «полк» должен был «стоять» три дня «за правду новгородскую». Если бы так легко было огодить фронт и отправиться всем скопом на Ярославово дворище в центр города, то с тем же успехом новгородцы могди сидеть по домам, «выставив дозор». Приведенный пример с походом 1217 г. касается иной ситуации: в НПЯ читается о движении войск по «пересеченной местности», где они еще не видели друг друга, и вполне могли даже «минуться в лесех» (разойтись в лесах, не встретив друг друга). Внезапное нападение чуди на новгородский лагерь и объяснялось тем, что новгородцы не знади, где находится войско противника. Но в 1255 г. речь фактически шла об осаде Новгорода. Таким образом, П. В. Аукин «филигранно смешивает» разнородные явления.

6) На с. 431, разбирая известие Лавр. 1178 г. (в книге о нем см. с. 147), рецензент пишет о том, что никаких противоречий в тексте нет, и что автор книги, предполагая в этом месте редактирование, предиагает читателям «совершенно искусственное и бездоказательное объяснение». ${ }^{68}$ Между тем, в книге на с. 147, прим. 132, сделана от-

(67) На с. 426-427 рецензии: «В 1255 г. новгородцы ожидали нападения на город Александра Невского с войском и поставиди полки «за Рожествомь Христовомь в конци» (имеется в виду церковь Рождества на кладбище) и «от святого Ильи противу Городища» (имеется в виду церковь Ильи на Славне). Далее говорится о вече у Николо-Дворищенского собора. Т. А. Вилкул усматривает тут противоречие и основание искать «какой-то иной код для прочтения» (с. 245). Но для человека, хотя бы раз бывавшего в Ведиком Новгороде и представляющего себе расстояния от указанных пунктов до Ярославова дворища, «иной код» не требуется: новгородцы (взрослые мужчины-воины) без особых затруднений могди прийти на вече, выставив дозор, как это делалось в подобных случаях, а потом вернуться обратно».

Кстати, предполагается, что автор книги не мог бывать в Новгороде Великом, и не имеет представления о реальных расстояниях. Небодьшая ремарка личного характера: в бытность студенткой я работала на Троицком раскопе в экспедиции В. А. Янина, и неплохо представляю себе расстояния в городе и округе.

(68) «Между тем, совершенно экспдицитно сказано (как и в НПЛ): «Князь же Всевододъ взя городъ Торжекъ...», отличие тодько в том, что в Лавр, где повествование более подробно, говорится специально о роди 
сылка к первой главе, с. 80, прим. 316, где отмечена несовместимость грамматических конструкций в тексте:

«Ср.: “...а сам перебравъ дружины нъколико, пха (ед. ч.) к Ламьскому Волоку, и пусти на воропъ, и пригнавше дружина, яша (мн. ч.) князя Мстиславича Ярослава, сыновця ему, а городъ пожже (ед. ч.), а людье бяху выбъгди, а жита пожгоша (мн. ч.) и до всего. Князь же Всеволодъ възвратися в Володимерь"; 387 А. Помимо всего прочего, конструкция с повторяющимся союзом “а" не предполагает вводных предложений, и чередуются сегменты с союзом “и” и союзом “а”. Все это также косвенно указывает на редактирование».

Кроме того, выше, на с. 146 приведен обширный фрагмент Лавр. В данном месте в суздальском своде обильное цитирование Библии, присущее пространным повествованиям, сочетается с формульным летописным нарративом, характерным для лаконичных сообщений летописей - напр., для НП за начало-середину XII в. Казалось бы, человека, читавшего летописи и знакомого с особенностями так называемых «летописных повестей» и летописных кратких известий (при всей условности этих обозначений), такое сочетание должно навести на размышления. Наконец, анализируя это известие, неплохо было бы заметить и такое обстоятельство, что в Лавр. перевернута последовательность событий: поход на Торжок - смерть Мстислава Ростиславича (в книге см. с. 147). ${ }^{69}$ То, что П. В. Аукин всего этого не заметил, вызывает вопрос: следует ии замечание рецензента о «бездоказательности и искусственности» отнести на счет его квалификации в области текстологии и лингвистики, или же это очередное сознательное искажение.

7) На с. 431-432 утверждается, что в известии НПЛ 1218 г. не говорится об участии в вечевых «междоусобных столкновениях» детей, «но просто говорится: «и тако быша въча по всю недъдю». Подобная интерпретация П. В. Аукина вновь отличается замечательной «простотою». Если принять такое толкование, тогда окажется, что в летописи зачем-то сообщалось о посторонних событиях, но тревожные «вЂча»,

дружины. Т. А. Вилкул цитирует эту фразу, но почему-то предлагает ей совершенно искусственное и бездоказательное объяснение, предполагая позднейшее редактирование (с. 147, сноска), хотя никаких противоречий в том, что при взятии города действуют и князь, и дружина, нет».

(69) Должно быть наоборот. Несоответствие отмечено Н. Г. Бережковым, и учтено при анализе параллельных известий НП и Лавр в моей книге. 
бывшие «по всю недъдю», ${ }^{70}$ почему-то не описывались и результат возник «из воздуха». По-видимому, следует учитывать, что союз «и тако» часто обозначает итоговое состояние. Т.е. иетописное «и тако быша въча во всю неделю» относится именно к тем столкновениям и убийствам, которые начадись с того, что князь захватил одного из новгородцев, и «ониполовици» (жители «оного пола», т.е. Торговой стороны) «възвониша» и «поидоша... и до дътии в бръняхъ». Кстати, в НП ся позднее, и касаются веча: 1270 г. «и съзвониша въче на Ярославди дворь и убиша Иванка»; 1299 г. «и съзвонивше въче у стои Софьи кйзь Борисъ Андръеви с со всъми новгородци».

8) На с. 431 П. В. Аукин пишет о том, что автор не приводит никаких расчетов размеров и вместимости площадей древнерусских городов, «что делает довод [о небольших площадях - Т. В.] голословным». Рецензент называет «голословным» утверждение, которое идет в таком контексте:

(с. 221) На незначительность площадей вечевых собраний обращали внимание В. А. Янин и П. П. Толочко. В. А. Янин локализует новгородское вече на Ярославовом дворище, на месте, занимаемом сейчас одним из церковных строений, и считает, что там могли поместиться несколько сотен (а именно, 300) человек. ${ }^{20}$ П. П. Толочко, полемизируя с И. Я. Фрояновым по поводу выражения «вси кияне от мала и до велика», справедливо отмечал, что на сравнительно небольшой двор киевской Софии вряд ли могди собраться все жители Киева ${ }^{21}$.

${ }^{20}$ В. А. Янин опирается на упоминание в немецком источнике XIV в. «трехсот золотых поясов». Янин В. А., Колчин Б. А. Археологии Новгорода - 50 лет. С. 117; Янин В. А. Социально-политическая структура. С. 92 и др. Правда, сообщение о «300 золотых поясах» 1331 г., вероятно, не является известием о вече. См.:

(70) Привожу, с некоторыми купюрами, выдержку из НП, , ПР , т. 3, с. 58-59: «и възвониша у святого Николы ониполовици цересь ночь, а Неревьскыи коньчь у Святыхъ 40, такоже копяче люди на Твьрдислава. И бысть заутра, пусти кН̈зь Матъя, учювъ гъ дку и мятежь въ городъ. И поидоша ониполовици и до дптии въ брьняхь, акы на рать, а неревляне такоже; а загородьци не въсташа ни по сихъ, ни по сихъ, нъ зряху перезора. Твьрдиславъ же, позря на святую Софию, и рече ... и поиде съ Людинемь концемь и съ пруси. И бысть сеця у городьныхъ воротъ ... чюдо свади оканьныи дияволъ... ся начяша бити межи собою; и убиша муж прус, а концянъ другыи, а оньхъподовиць Ивана Душильцевиця ... Бысть же се мъсяця генваря... и тако быша въча по всю недъдю». 
Расмуссен К. «300 золотых поясов» древнего Новгорода // SkandoSlavica. Т. 25 (Copenhagen, 1979), 97; Чебанова Е. И. «300 золотых поясов»: проблемы интерпретации термина // Проблемы социального и гуманитарного знания. СПб., 1999. С. 166-182; Гранберг Ю. Совет господ Новгорода в немецких источниках // ДГ 1998. М., 2000. С. 78-87; Андреев В. Ф. О социальном составе новгородского веча // Генезис и развитие феодализма в России. А., 1989. Вып. 11. С. 73-74. Тем не менее, мысль о небольшой вместимости вечевой площади, по-видимому, верна.

${ }^{21}$ Толочко П. П. Киев и Киевская земля. С. 108-109. Согласно демографическим реконструкциям, в крупных древнерусских городах могло проживать от 10 до 50 тыс. чел. Толочко П. П. Древнерусский феодальный город. К., 1989. С. 201. В Новгороде, например, насчитывалось 4-5 тыс. дворов: Андреев В. Ф. О социальном составе. С. 77-78. НП , описывая пожар, захвативший весь город, называет цифру в 4300 сгоревших дворов; HI, с. 52.

Как видим, в книге приведены ссылки на работы В. Я. Янина и П. П. Толочко, признанных специалистов в области древнерусской археологии; затронут вопрос о так называемых «300 золотых поясах». Между прочим, этих ссылок невозможно не заметить, и значит, в данном случае можно уже уверенно утверждать о сознательном искажении П. В. Аукиным содержания рецензируемой им монографии.

Примеры можно было бы продолжать, но, думается, этого достаточно. На последних страницах П. В. Аукин представдяет своеобразное резюме:

«Хайден Уайт и другие, главным образом, заокеанские ученые не могут нести ответственность за то, как их “интерпретируют" на постсоветском пространстве. Однако в самом обращении таких авторов, как Т. А. Вилкул, к “нарративизму” и “деконструкции” есть, как представляется, определенная закономерность... Мы имеем дело не с банальным “культурологическим” словоблудием, и не с научным исследованием в настоящем смысле слова, а с имитацией последнего, претендующей на то, чтобы “деконструировать” якобы устаревшую позитивную науку и подменить ее вульгарной идеологией» (с. 433-434).

Как уже отмечалось, рецензент не полемизирует с идеями моей книги и не освещает ее содержание. Ни одно основное положение ему опровергнуть не удалось. Если в рецензии пишется о некоем капитальном утверждении в книге, то на деле часто оказывается, что речь идет о примечании или части примечания. Далее, 
П. В. Аукин позволяет себе значительное количество неверных утверждений, по его собственной терминологии - «с массой передергиваний и выборочного цитирования». Эти заведомо ложные высказывания вряд ди допустимы в профессиональной научной работе. Зачастую рецензент демонстрирует недостаточное знакомство с материалом, что ставит под вопрос его квалификацию для вынесения суждений по многим вопросам: «простые мысди», недочитывание текстов источников и текстодогически некорректные интерпретации являются достоянием рецензии П. В. Аукина. Все это делает его претензии на освещение научности моей книги, мягко говоря, сомнительными.

Что касается того тезиса, что нормальная наука есть наука традиционная, новаторство же представляется рецензенту вульгарной идеологизирующей «лженаукой». Относительно новаторства, рискуя повториться, скажу, что тема веча чрезвычайно трудна для современного исследователя, поскольку очень многое сделано предыдущими поколениями историков. По сути, существуют два пути: искать новое либо же «забывать» сделанное другими и пытаться перелицовывать историографию. ${ }^{71} \mathrm{O}$ «вульгаризации»: как я попыталась выше показать, к «простоте» и «простой мысли» часто апеллирует именно рецензент, тогда как на деле речь идет о достаточно сложных явлениях. «Идеологичность» проявляется еще более ярко. В ряде мест отчетливо видно, как П. В. Лукин манипулирует текстами и подстраивает их под собственные воззрения. Для оценки же качества идеологической риторики приводятся выдержки из его рецензии.

Напоследок, несколько пожеланий относительно ведения полемики. Видимо, было бы лучше, если бы П. В. Аукин не искажал положения книги, обсуждаемые в его рецензии. Представдяется, что рецензенту следует корректно и полностью прочесть источники, прежде чем делать какие-либо высказывания по поводу неверной интерпретации. Неплохо было бы также, если бы П. В. Аукин не пытался выдать свое видение проблем, во многих случаях, весьма упрощенное и, зачастую - просто неверное, за единственно правильное.

(71) Кстати сказать, П. В. Аукин, как видно хотя бы из его недавней работы: раздела «Вече: социальный состав» в кн.: Древняя Русь. Очерки политического и социильного строя (Москва, 2008), - избрал второй путь. В историографическом разделе его труда среди ученых 2-й половины XX - начала XXI вв. очень бегло названы В. А. Янин (со ссылкой на одну (!) работу), П. П. Толочко (вообще без ссылок!), не назван М. Б. Свердлов (! тема веча рассматривается в нескольких книгах российского ученого) и другие. 
Не говоря уже о том, рецензент должен был бы, по крайней мере, понимать содержание рецензируемого им труда. Разумеется, П. В. Яукину вольно ощущать себя блюстителем российской исторической науки. Однако, проводя свои «деконструкции», исследователь допустил массу разнообразных ошибок и прибег к сознательному подлогу, покусившись на суверенитет читателя и навязывая ему свое толкование содержания книги. Все это позволяет видеть иные мотивы рецензии, чем просто отстаивание истины... Какие это мотивы - личные, политические, идеологические - решать читателю монографии, рецензии на нее и двух ответов. ${ }^{72}$

(72) (Это прим. написано после написания основного текста). Как мне стало известно, П. В. Лукин написал ответ на мой ответ, в марте этого года; московский коллега имел возможность работать с рукописью моего текста, дюбезно предоставленной ему издателем Scrinium. Позднее издатель любезно объяснил мне, что в редакции принято решение предоставить еще раз слово Аукину, и на этом полемику закрыть. Решение, как представляется, совершенно верное, совпадающее и с моими собственными намерениями. Кроме всего прочего, полемика с исследователем, пытающимся «проверять» древнеславянский текст по Синодадьному переводу, может быть сколь угодно прододжительной, но, тем не менее, бесплодной. Итак, в следующем номере Scrinium продолжения не последует. 